Article

\title{
Lysophosphatidic Acid-Activated Calcium Signaling Is Elevated in Red Cells from Sickle Cell Disease Patients
}

\author{
Jue Wang ${ }^{1}$, Laura Hertz ${ }^{2,3}$, Sandra Ruppenthal ${ }^{3,4}$, Wassim El Nemer ${ }^{5,6}$ (D) Philippe Connes ${ }^{6,7}$ (D), \\ Jeroen S. Goede ${ }^{8}$, Anna Bogdanova ${ }^{9}$ (D), Lutz Birnbaumer 10,11 and Lars Kaestner ${ }^{2,3, *}$
}

check for updates

Citation: Wang, J.; Hertz, L.; Ruppenthal, S.; El Nemer, W.; Connes,

P.; Goede, J.S.; Bogdanova, A.;

Birnbaumer, L.; Kaestner, L.

Lysophosphatidic Acid-Activated Calcium Signaling Is Elevated in Red Cells from Sickle Cell Disease Patients. Cells 2021, 10, 456. https: / / doi.org/10.3390/cells10020456

Academic Editor: Saverio Marchi

Received: 26 January 2021

Accepted: 17 February 2021

Published: 20 February 2021

Publisher's Note: MDPI stays neutral with regard to jurisdictional claims in published maps and institutional affiliations.

Copyright: (c) 2021 by the authors. Licensee MDPI, Basel, Switzerland. This article is an open access article distributed under the terms and conditions of the Creative Commons Attribution (CC BY) license (https:/ / creativecommons.org/licenses/by/ $4.0 /)$.
1 Department of Cellular and Molecular Biology, The University of Texas Health Science Center at Tyler, Tyler, TX 75708, USA; anjwan@googlemail.com

2 Theoretical Medicine and Biosciences, Saarland University, 66421 Homburg, Germany; laurahertz@gmx.de

3 Experimental Physics, Dynamics of Fluids, Saarland University, 66123 Saarbrücken, Germany; slruppenthal@gmx.de

4 Gynaecology, Obstetrics and Reproductive Medicine, Saarland University Hospital, 66421 Homburg, Germany

5 Etablissement Français du Sang PACA-Corse, Aix Marseille Université, EFS, CNRS, ADES, 13005 Marseille, France; wassim.el-nemer@efs.sante.fr

6 Laboratoire d'Excellence GR-Ex, 75015 Paris, France; pconnes@yahoo.fr

7 Laboratory LIBM EA7424, Vascular Biology and Red Blood Cell Teal, University Claude Bernard Lyon 1, 69008 Lyon, France

8 Division of Oncology and Hematology, Kantonsspital Winterthur, CH-8401 Winterthur, Switzerland; Jeroen.goede@ksw.ch

9 Red Blood Cell Research Group, Institute of Veterinary Physiology, University of Zürich, CH-8057 Zürich, Switzerland; annab@access.uzh.ch

10 Institute of Biomedical Research (BIOMED), Catholic University of Argentina, C1107AFF Buenos Aires, Argentina; birnbau1@gmail.com

11 Laboratory of Neurobiology, National Institute of Environmental Health Sciences, Research Triangle Park, NC 27709, USA

* Correspondence: lars_kaestner@me.com

Abstract: (1) Background: It is known that sickle cells contain a higher amount of $\mathrm{Ca}^{2+}$ compared to healthy red blood cells (RBCs). The increased $\mathrm{Ca}^{2+}$ is associated with the most severe symptom of sickle cell disease (SCD), the vaso-occlusive crisis (VOC). The $\mathrm{Ca}^{2+}$ entry pathway received the name of $\mathrm{P}_{\text {sickle }}$ but its molecular identity remains only partly resolved. We aimed to map the involved $\mathrm{Ca}^{2+}$ signaling to provide putative pharmacological targets for treatment. (2) Methods: The main technique applied was $\mathrm{Ca}^{2+}$ imaging of RBCs from healthy donors, SCD patients and a number of transgenic mouse models in comparison to wild-type mice. Life-cell $\mathrm{Ca}^{2+}$ imaging was applied to monitor responses to pharmacological targeting of the elements of signaling cascades. Infection as a trigger of VOC was imitated by stimulation of RBCs with lysophosphatidic acid (LPA). These measurements were complemented with biochemical assays. (3) Results: $\mathrm{Ca}^{2+}$ entry into SCD RBCs in response to LPA stimulation exceeded that of healthy donors. LPA receptor 4 levels were increased in SCD RBCs. Their activation was followed by the activation of $G_{i}$ protein, which in turn triggered opening of TRPC6 and Cav2.1 channels via a protein kinase $\mathrm{C} \alpha$ and a MAP kinase pathway, respectively. (4) Conclusions: We found a new $\mathrm{Ca}^{2+}$ signaling cascade that is increased in SCD patients and identified new pharmacological targets that might be promising in addressing the most severe symptom of SCD, the VOC.

Keywords: erythrocytes; sickle cell disease; LPA receptor; G protein signaling; transgenic mice; protein kinase $\mathrm{C} \alpha$; MAP kinase; TRPC6; $\mathrm{Ca}_{\mathrm{V}} 2.1$; Gárdos channel

\section{Introduction}

In sickle cell disease (SCD) patients' red blood cells (RBCs), the $\mathrm{Ca}^{2+}$ uptake is increased to approximately $300 \mu \mathrm{mol} /\left(1_{\text {cells }} \mathrm{h}\right)$ during vaso-occlusive crisis (VOC), which is 
approximately 6-fold higher than in healthy RBCs [1,2]. This $\mathrm{Ca}^{2+}$ overload is likely to be mechanistically involved in the generation of the VOC, e.g., favoring RBC dehydration that promotes crystallization of deoxyHbS. However, the deoxygenation of $\mathrm{HbS}$ alone is insufficient to explain the erratic nature of the crises [3]. Dehydration occurs due to Gárdos channel $\left(\mathrm{Ca}^{2+}\right.$-activated $\mathrm{K}^{+}$channel, $\mathrm{KCNN} 4, \mathrm{~K}_{\mathrm{Ca}} 3.1$, hSK4) activation and the following $\mathrm{K}^{+}$loss increases the mean cellular hemoglobin concentration (MCHC) and promotes $\mathrm{HbS}$ aggregate formation. Furthermore, $\mathrm{Ca}^{2+}$ overload promotes phosphatidylserine externalization already in healthy RBCs [4] but in particular in RBCs of SCD patients [5], and as such increases the aggregability of RBCs [6] and their intercellular adherence [7]. Thus, the increased $\mathrm{Ca}^{2+}$ may promote the perturbation of microcirculation with participation of even non-deoxygenated cells, independent of dehydration. This would increase RBC transit time in poorly oxygenated vascular areas and further increase the risks for VOC.

The $\mathrm{Ca}^{2+}$ increase was named $\mathrm{P}_{\text {sickle }}$ due to its conductive nature but without any knowledge about its molecular identity [8,9]. However, in recent years, it became obvious that more than one ion channel is involved in $\mathrm{P}_{\text {sickle }}[10,11]$. One direct $\mathrm{Ca}^{2+}$ entry pathway, which is elevated in SCD RBCs, was shown to be the NMDA receptor [12,13]. A recent clinical trial with memantine, an antagonist of the NMDA receptor, showed promising results $[14,15]$. Here we provide evidence for a further player, lysophosphatidic acid (LPA), that activates a signaling cascade, leading to increased intracellular $\mathrm{Ca}^{2+}$ and this $\mathrm{Ca}^{2+}$ entry pathway is upregulated in RBCs of SCD patients. LPA-induced $\mathrm{Ca}^{2+}$ entry into RBCs was previously shown and believed to be channel mediated $[16,17]$.

Whereas pharmacological studies pointed to the Cav2.1 channel $[17,18]$, patch-clamp measurements of channel activity gave rise to an alternative hypothesis that, instead, a non-selective cation channel might cause the $\mathrm{Ca}^{2+}$ influx $[19,20]$. Although LPA-induced $\mathrm{Ca}^{2+}$ influx was phenomenologically characterized [21-23], very little is known about the signaling pathways resulting in LPA-dependent ion channel activation. It is known that LPA activates protein kinase $\mathrm{C} \alpha(\mathrm{PKC} \alpha)[18,21,24]$, which is among the conventional and novel PKC isoforms and, according to current knowledge, the only abundant variant occurring in RBCs [25]. However, a putative interaction between PKC and the Cav 2.1 channel is rather controversial $[18,24,26]$. Therefore, we aimed to further elucidate the signaling pathway from LPA stimulation of RBCs to the $\mathrm{Ca}^{2+}$ entry mechanisms in healthy and SCD RBCs.

\section{Materials and Methods}

\subsection{Preparation of Human and Mouse Blood Samples}

Experiments with human RBCs were authorized by the 'Ärztekammer des Saarlandes' under registration number 132/08 for healthy donors and by the Canton Zürich ethics committee under registration number KEK ZH NR 2010-0237 as well as by the regional ethics committee CPP Sud/Ouest Outre Mer III, Bordeaux under registration number 2010-A00244-35 for SCD patients. In all cases, blood donors provided their written informed consent to participate in this study. This consent procedure was approved by the respective ethics committees under the above-mentioned study registration numbers. For the experiments, we used RBCs from healthy adult donors and non-transfused HbSS SCD patients. Blood was drawn from a vein into heparinized containers and used within $30 \mathrm{~h}$ of the withdrawal.

Experiments with mouse blood were carried out in strict accordance with the recommendations in the Guide for the Care and Use of Laboratory Animals of the National Institutes of Health. The protocol was approved by the State Office for Health and Consumer Protection (Permit Number: C1-2.4.3.4). All efforts were made to minimize suffering. Blood samples were collected from the cheeks of the mice by lancet puncture and were collected into heparinized Eppendorf tubes.

The following procedure was followed identically for RBCs from human and mouse. $\mathrm{RBCs}$ were isolated via centrifugation at $5000 \times g$ for $3 \mathrm{~min}$. The buffy coat and plasma were discarded, and the remaining RBCs were washed three times with Tyrode solution (Tyrode) 
containing the following components (in $\mathrm{mM}$ ): $135 \mathrm{NaCl}, 5.4 \mathrm{KCl}$, 10 glucose, $1 \mathrm{MgCl}_{2}$, $1.8 \mathrm{CaCl}_{2}$ and 10 HEPES. The $\mathrm{pH}$ was adjusted to 7.35 using NaOH. For imaging the cells were loaded with Fluo-4 AM (Molecular Probes, Eugene, OR, USA) at a concentration of $5 \mu \mathrm{M}$ for $1 \mathrm{~h}$ at $37^{\circ} \mathrm{C}$. Then, the cells were washed three times with Tyrode.

\subsection{Microscopic Video Imaging to Measure Intracellular $\mathrm{Ca}^{2+}$}

Life-cell imaging was performed to monitor intracellular $\mathrm{Ca}^{2+}$ kinetics in individual cells treated with hormones and pharmaceuticals (see below). Fluo-4-loaded cells were plated onto coverslips. We waited $15 \mathrm{~min}$ for cell sedimentation and dye de-esterification. Fluorescence was measured on the stage of an inverted microscope (TE2000, Nikon, Tokyo, Japan) equipped with a $60 \times$ Plan Apo 1.4 objective. A video imaging device (TILL Photonics, Munich, Germany) was attached to the microscope and contained a monochromator (Polychrome IV), a camera (Imago), the imaging control unit and acquisition software (TILLvision V4.0) for Figures 1, 3, 4, 6 and 8. The system was upgraded to Polychrome V, a sCMOS camera (Flash4, Hamamatsu Photonics, Hamamamtsu City, Japan) and the software (LightAcquisition, FEI, Munich, Germany) before the experiments presented in Figures 5, 7 and 9 were carried out. Fluo-4-loaded cells were excited at $480 \mathrm{~nm}$, and the resulting fluorescence images (using a $505 \mathrm{~nm}$ long pass dichroic mirror and a 535/40 bandpass filter) were collected every $5 \mathrm{~s}$ for $15 \mathrm{~min}$. A gravity-driven local perfusion system was utilized to quickly exchange solutions in the field of view. All measurements were performed at room temperature $\left(\sim 22^{\circ} \mathrm{C}\right)$. The images were analyzed in ImageJ (Wayne Rasband, National Institute of Mental Health, Bethesda, MD, USA), and the traces were further processed by IGORpro software (WaveMetrics, Kake Oswego, OR, USA).

\subsection{Stimulating Substances}

All activators and inhibitors were of analytical grade and freshly prepared from frozen stock solution. The stock solution of LPA was $5 \mathrm{mM}$ dissolved in phosphate-buffered saline (PBS, Sigma-Aldrich, St. Louis, MO, USA). Pertussis toxin (PTX, Sigma-Aldrich) was dissolved at a concentration of $250 \mu \mathrm{g} / \mathrm{mL}$ in $\mathrm{H}_{2} \mathrm{O}$. U0126 as well as Wortmannin (both Sigma-Aldrich) were dissolved at $10 \mathrm{mM}$ in DMSO (Roth, Karlsruhe, Germany). Gö6976 (Tocris Biosciences, Bristol, UK) was dissolved at $1 \mathrm{mM}$ in DMSO and $\omega$-agatoxin-TK (Peptanova, Sandhausen, Germany) at $100 \mu \mathrm{M}$ in $\mathrm{H}_{2} \mathrm{O}$. For $\mathrm{AlF}_{4}{ }^{-}, 30 \mu \mathrm{M} \mathrm{AlCl}_{3}$ and $10 \mathrm{mM}$ $\mathrm{NaF}$ were mixed. FK506 (InvivoGen, Toulouse, France) was dissolved at $20 \mathrm{mM}$ in DMSO and Cyclosporin A (Alfa Aesar, Ward Hill, MA, USA) at $1 \mathrm{mM}$ in ethanol.

\subsection{Western Blots}

For Western blots, RBCs were filtered to make sure samples were not contaminated by mononuclear cells [27]. Briefly, $0.36 \mathrm{~g}$ of a mixture of equal parts by weight of microcrystalline cellulose (cod. S5504, Sigma-Aldrich) and $\alpha$-cellulose (cod. C8002, Sigma-Aldrich) were mixed with $10 \mathrm{~mL}$ Tyrode to obtain a homogeneous slurry. The barrel of a $5 \mathrm{~mL}$ plastic syringe was used as the filtering device and a septum made of filter paper (Whatman ${ }^{\circledR}$ No 4, Cod. 1004125, Schleicher \& Schuell BioScience, Dassel, Germany) was placed on the bottom of the syringe barrel. The cellulose slurry was carefully poured inside the syringe and the cellulose allowed to settle evenly. The excess Tyrode was allowed to flow through, exposing the surface of the cellulose bed. At this point, $1 \mathrm{~mL}$ of blood sample was carefully layered on top of the cellulose. When all the blood had entered the cellulose bed, Tyrode was added to the filter, and the fraction of filtered RBCs was collected. The filtered cells were concentrated by centrifugation and washed two more times with Tyrode. HeLa cells used as positive controls were handled as previously described [28].

Cells were lysed by EP extraction buffer ( $100 \mathrm{mM}$ Tris-HCl, $100 \mathrm{mM} \mathrm{NaCl}, \mathrm{pH} 7.5)$ supplemented with $0.5 \%$ Triton X-100, $20 \mathrm{mM}$ DTT, complete protease inhibitor cocktail and Phospho Stop (Roche Applied Science, Mannheim, Germany) on ice for $30 \mathrm{~min}$. The wholecell lysates were then centrifuged at $5000 \times g$ for $10 \mathrm{~min}$. The cell lysate was separated on $12 \%$ polyacrylamide gels. The gel electrophoresis was followed by transfer to nitrocellulose 
transfer membranes (Protran, Whatman, Kent, UK). Blots were incubated with rabbit polyclonal anti-GAPDH (1:15,000), anti-LPAR 1 (1:2000), anti-LPAR 2 (1:1000), anti-LPAR 3 (1:1000, all antibodies LifeSpan BioScience, Seattle, WA, USA), anti-LPAR 4 (1:1000), anti-LPAR 5 (1:1000, both from Aviva Systems Biology, San Diego, CA, USA).

Blots were washed with phosphate-buffered saline with $0.1 \%$ tween-20 (PBS-T) and incubated with the horseradish peroxidase (HRP)-conjugated antibodies (1:5000). Enhanced chemiluminescence (ECL) was used for signal detection.

\subsection{Immunostainings and Confocal Measurements}

For LPA receptor immunostainings, RBCs were fixed with $2 \%$ PFA plus $0.0075 \%$ glutaraldehyde in Tyrode for $30 \mathrm{~min}$. Then cells were permeabilized with $0.3 \%$ Triton X-100 in Tyrode for $10 \mathrm{~min}$, followed by centrifugation at $3700 \times g$ for $5 \mathrm{~min}$. After blocking with $5 \%$ bovine serum albumin (BSA) in Tyrode for $20 \mathrm{~min}$, cells were incubated with the first antibody, such as LPAR1-5 (1:50), in blocking buffer (5\% BSA in Tyrode) for $4 \mathrm{~h}$ at room temperature while gently shaking. After washing in Tyrode3 times, cells were incubated with Alexa Fluor 488 goat anti-rabbit IgG (1:400; Molecular Probes, Eugene, OR, USA) in Tyrode for $2 \mathrm{~h}$. Confocal recordings were performed on a Leica TSC SP5II microscope (Leica, Mannheim, Germany) using a $63 \times$ oil immersion objective with a numerical aperture of 1.4 (HCX PL APO) as described recently [29]. Fluorescence images were acquired in the laser scanning mode using Leicas hybrid detector (HyD) at an excitation of $488 \mathrm{~nm}$, and the emission was collected between 491 and $540 \mathrm{~nm}$ for the Alexa Fluor secondary antibody. Bright field images were recorded with a Leica DFC290 camera. The Leica Application Suite Advanced Fluorescence (LAS AF) was used for image acquisition while ImageJ (Wayne Rasband, National Institute for Mental Health) was used for image processing, i.e., z-projection of the confocal slices, adjustment of brightness and contrast as well as allocation of a green look-up table.

\subsection{ELISA Phosphorylation Assay}

For the ELISA phosphorylation assay, the RayBio ${ }^{\circledR}$ Phospho-Erk1 (T202/Y204)/Erk2 (T185/Y187) ELISA Kit was used to detect MAPK phosphorylation, following the manufacturer's protocol. In brief, RBCs from healthy donors and SCD patients were treated with Tyrode (control) or $5 \mu \mathrm{M}$ LPA for $15 \mathrm{~min}$. After RBC lysis using the cell lysate buffer provided in the kit, $100 \mu \mathrm{L}$ sample or positive control (A431S002-1, provided by kit) to Erk1/2 was placed on a coated microplate. The cell lysates were incubated for $2.5 \mathrm{~h}$ at room temperature while shaking. After washing the plates 4 times with the wash solution provided by the kit, they were incubated with $100 \mu \mathrm{L}$ detection antibody anti Erk1 (T202/Y204)/Erk2 (T185/Y187) for $1 \mathrm{~h}$ while shaking. Then $100 \mu \mathrm{L}$ of prepared $1 \mathrm{x}$ HRP-conjugated anti-rabbit IgG was added to each well and incubated for $1 \mathrm{~h}$ at room temperature while shaking. After washing another 3 times, $100 \mu \mathrm{L}$ of TMB one-step substrate reagent was added to each well and incubated for $30 \mathrm{~min}$ at room temperature in the dark while shaking. Then $50 \mu \mathrm{L}$ of stop solution (Item I) was added to each well and read immediately at $450 \mathrm{~nm}$ in a PT-FUJI-SCANNER.

\subsection{Data Analysis}

Single-cell traces were analyzed as previously described in detail [30]. All data were tested for Gaussian distribution. If normality was passed, data are presented as the mean values \pm SEM in bar graphs. Otherwise, data are presented in box plots. The number under each box plot is the cell number. All experiments were performed on at least 3 different donors/patients or 3 individual mice.

According to the normality test and the grouping conditions for testing significance, Student's t-test, a Mann-Whitney test, an ordinary one-way ANOVA or a Kruskal-Wallis test with Tukey's or Dunn multiple comparison test was performed. The level of statistical significance was indicated as $p<0.05\left(^{*}\right), p<0.01\left({ }^{* *}\right), p<0.001\left({ }^{* *}\right)$ and $p>0.05$ (ns) for not significant. All statistical tests were performed in Prism, GraphPad, La Jolla, CA, USA. 


\section{Results}

3.1. LPA-Induced Increase in Intracellular $\mathrm{Ca}^{2+}$ in RBCs-Comparison of Healthy Donors with SCD Patients

Based on LPA stimulation of single RBCs and the previously introduced fluorescence microscopy analysis method [16,30], we compared $\mathrm{Ca}^{2+}$ entry in RBCs of healthy donors and SCD patients (Figure 1). In Figure 1, we provide representative examples of how the analysis was performed from imaging all the way to the statistical analysis. Figure $1 \mathrm{~A}$ shows representative images and single-cell traces for healthy RBCs; Figure 1B shows the corresponding data for SCD RBCs. The statistical analysis in Figure $1 \mathrm{C}$ depicts a significantly higher LPA-induced increase in the intracellular $\mathrm{Ca}^{2+}$ in sickle cells compared to healthy RBCs. Please note that also under control conditions we find a small LPAindependent $\mathrm{Ca}^{2+}$ entry. Although the topic of this report is LPA-dependent $\mathrm{Ca}^{2+}$ entry, this rather small (fractual) $\mathrm{Ca}^{2+}$ influx contributes to the entire picture of the $\mathrm{Ca}^{2+}$ signaling (see Discussion below).

\subsection{LPA Receptors in Healthy and SCD RBCs}

Since the $\mathrm{Ca}^{2+}$ increase in both healthy and SCD RBCs is caused by the application of LPA, it was a logical step to look at the abundance of LPA receptors in RBCs. Figure 2A shows Western blots and their analysis of the LPA receptors $1-5$, which reveal the presence of LPA receptors 1, 2 and 4 in healthy and sickle RBCs, with receptor 4 being significantly increased in SCD RBCs. The immunocytochemistry data and their statistical analysis in Figure 2B clearly support the results of the Western blot. The full gel Western blots for all conditions are provided in Supplemental Figure S1.

\subsection{G Protein Signaling}

To further explore the molecular signaling pathway, we followed the hints of the literature towards the involvement of G proteins [31] by comparing the LPA stimulation with the broad $\mathrm{G}$ protein activation by $\mathrm{AlF}_{4}{ }^{-}$[32] in human and mouse RBCs (Figure 3A). Although the magnitudes of the response are slightly different between human and mouse RBCs, both depict a significant increase in intracellular $\mathrm{Ca}^{2+}$ even exceeding the LPA stimulation. Following the literature, we probed the LPA stimulation in RBCs of a G $\alpha_{11}$ knock-out mouse line [33], revealing no difference to cells of wild-type mice (Figure 3B). The next candidate of $G$ proteins to probe was the $G \alpha_{i}$ utilizing the specific inhibitor PTX [34]. PTX fully inhibits LPA-induced $\mathrm{Ca}^{2+}$ entry in mouse RBCs (Figure 3C), leading to the conclusion that the LPA mechanism is exclusively operated by $\mathrm{G} \alpha_{i}$ proteins. The same $\mathrm{G} \alpha_{\mathrm{i}}$-based mechanism seems to be operating in human RBCs (Figure 3D).

\subsection{The PKC Branch of the Signaling Pathway of G Protein Signaling}

Because $G \alpha_{i}$ subunits have been associated with the transient receptor potential (TRP) channels C4 and C5 [35], we investigated RBCs fromTRPC4/5 double knock-out mice [36]. As shown in Figure 4A, there is no significant difference in $\mathrm{Ca}^{2+}$ entry of TRPC4/5 ${ }^{-/-} \mathrm{RBC}$ compared to WT RBCs. Because TRPC6 has been reported to contribute to the increase in residual $\mathrm{Ca}^{2+}$ influx in $\mathrm{RBC}$ [37], we further investigated RBCs of TRPC6 ${ }^{-/-}$mice [36,37]. The stimulation with LPA revealed that $\mathrm{Ca}^{2+}$ entry in TRPC6 ${ }^{-/-} \mathrm{RBC}^{2}$ is suppressed, but still significantly increased compared to control conditions (Figure 4A). Due to the proposed involvement of PKC $\alpha$ in RBCs channel regulation $[18,24,38]$, we inhibited PKC $\alpha$ with the specific inhibitor Gö6976 [39]. The results are depicted in Figure 4B. In RBCs of wild-type mice, inhibition of PKC $\alpha$ lead to a decrease in $\mathrm{Ca}^{2+}$ influx, which is still higher than that under control conditions. For TRPC6 ${ }^{-/-}$mice, Gö6976 had no additional effect on LPA-induced $\mathrm{Ca}^{2+}$ entry. In human RBCs (both healthy and SCD), the relative amount of Gö6976-inhibited $\mathrm{Ca}^{2+}$ entry is identical compared to wild-type mouse conditions (Figure 4C). In addition, we considered the application of TRPC6 inhibitors, in particular larixyl acetate [40] and SAR7334 [41] at the suggested concentrations. However, as depicted in Supplemental Figure S2, both inhibitors show non-specific side effects that result rather 
in a $\mathrm{Ca}^{2+}$ increase instead of an inhibition. This is clearly seen when applied to RBCs of TRPC6 $^{-/-}$mice.

$\boldsymbol{A}$
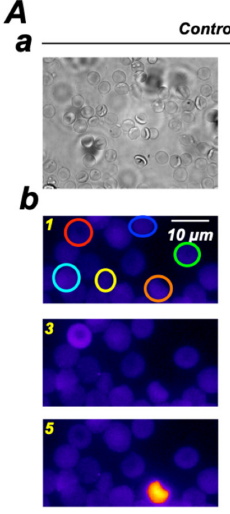

Tyrode

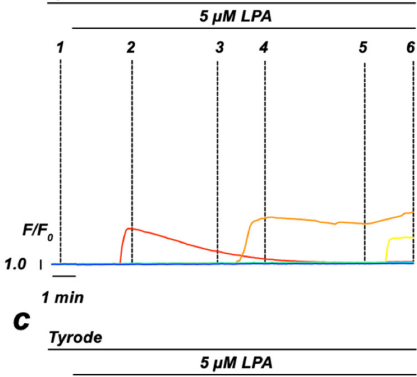

c

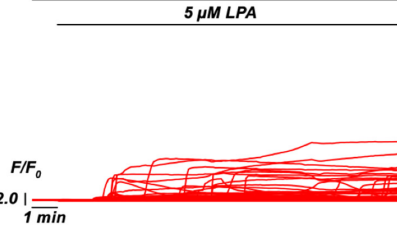
Tyrode

d
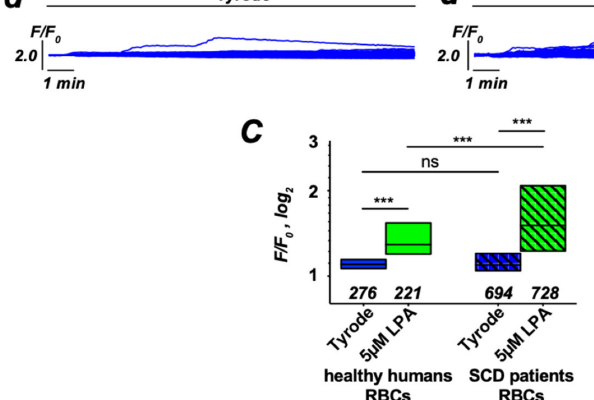

Ba
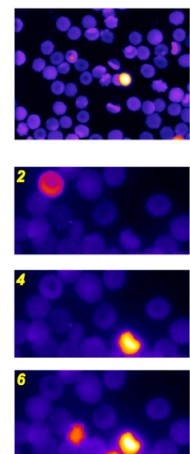

\section{.}

\section{西}

$c^{1 \overline{m i n}}$

C

RBCs
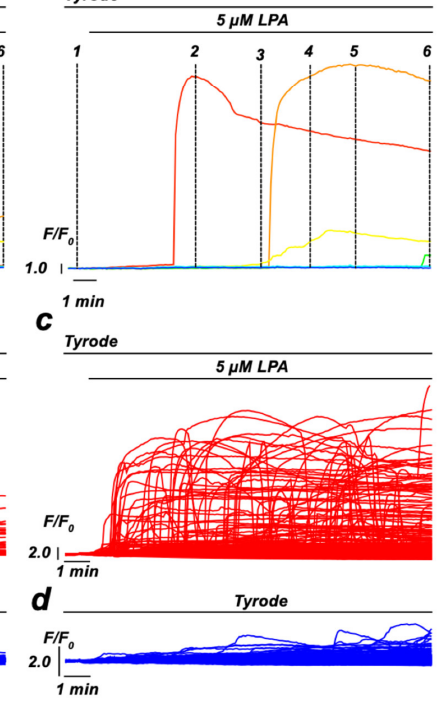

Figure 1. LPA-induced increase in intracellular $\mathrm{Ca}^{2+}$ in RBCs from healthy donors compared to HbSS SCD patients. (A) depicts the measurements for healthy control cells, while (B) shows the same approach for RBCs from SCD patients. (a) shows bright field images and fluorescence images under unstimulated control conditions. (b) Representative image sections with RBCs marked with regions of interest $(\mathrm{ROI})$ in different colors. In the traces below the images, the fluorescence intensities (selfratio $\mathrm{F} / \mathrm{F}_{\mathrm{o}}$ ) of the cells marked (same color codes as the ROI) are plotted. The bars above the traces indicate the presence/application of the external solution. Numbers at the dashed lines correspond to the numbers of the images above. (c) gives the collection of all fluorescence intensity traces (similar as in (b)) but for all cells measured with LPA stimulation. (d) shows the same as in (c) for control experiments without stimulation. (C) Statistical analysis of the max. value of each trace as outlined in (b-d). Since cellular values are not Gaussian distributed, statistics show medians and 10-90\% boxes. Numbers below the boxes refer to the number of cells analyzed originating from at least three different experiments. ns stands for not significant $(p>0.05)$ and ${ }^{* * *}$ for $p<0.001$. All measurements were performed at room temperature. 


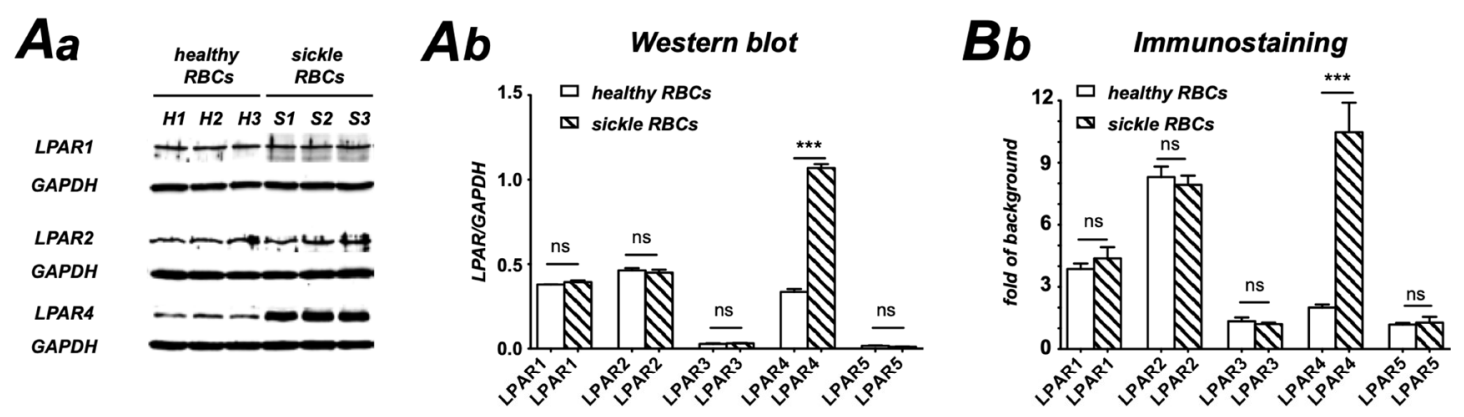

\section{Ba healthy humans}
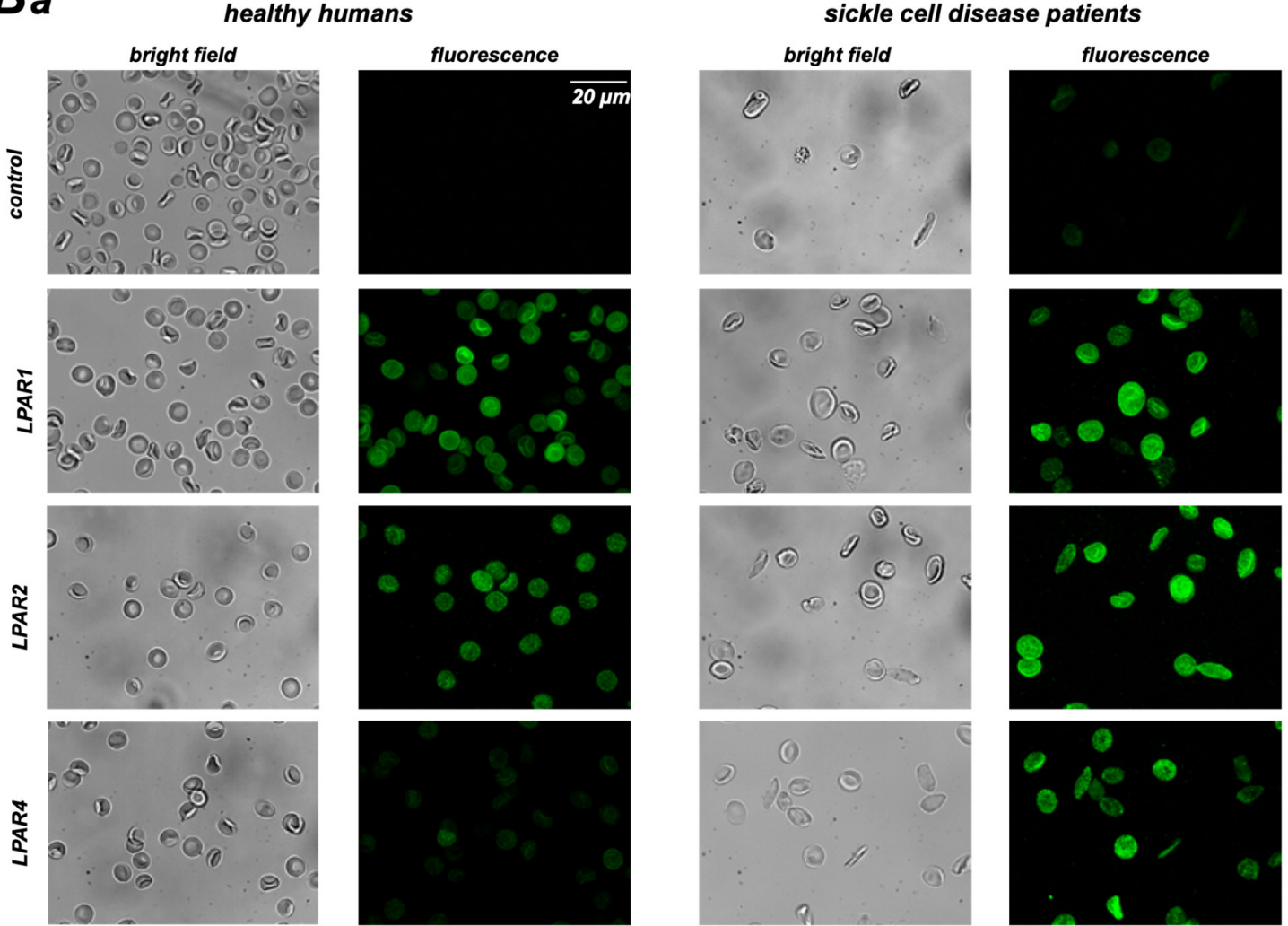

Figure 2. LPA receptors (LPAR) in RBCs from healthy donors compared to SCD patients. (Aa) depicts the Western blots of LPAR 1, 2 and 4 for healthy RBCs (H1-H3) and sickle cells (S1-S3). As a loading control, we used GAPDH. (Ab) shows the statistical analysis of the Western blots as presented in (Aa). For LPARs 3 and 5, the bands were below the detection limit. Examples of full gel Western blots for all LPA receptors tested are provided in Supplemental Figure S1. (Ba) shows confocal z-projections of immunocytochemistry staining for control conditions (only secondary Alexa Flour 488-labeled antibody) and for the three abundant LPARs in comparison to brightfield images of healthy (left) and SCD (right) RBCs. Even if the cell number in particular images is rather low, we ensure that they are representative for the cell population. (Bb) summarizes the statistical analysis of the immunostainings as depicted in (Ba) supporting the Western blot data. ns stands for not significant $(p>0.05)$ and ${ }^{* * *}$ for $p<0.001$.

As shown in Figure 4, we could link PKC $\alpha$ activity to TRPC6-mediated $\mathrm{Ca}^{2+}$ entry. We were puzzled by this finding, because phosphorylation of TRPC6 by PKC isoforms is commonly associated with the inhibition of TRPC6 [42]. However, Kim and Saffen proposed that the PKC-induced phosphorylation of TRPC6 and its inactivation enable the binding of the immunophilin FKBP12 to TRPC6, eventually forming a multiprotein complex with calcineurin and calmodulin [43]. The calcineurin then dephosphorylates TRPC6 and in turn activates the channel [43]. This interaction scheme is sketched in Figure 5A. To test whether this mechanism might be responsible for PKC $\alpha$-induced TRPC6 activity in RBCs, we compared LPA-induced $\mathrm{Ca}^{2+}$ influx of human RBCs under Gö6976 
pretreatment with that of RBCs pretreated with FKBP12 inhibitor FK506 and the calcineurin inhibitor Cyclosporin A (CsA) (Figure 5B). FK506 suppresses LPA-induced $\mathrm{Ca}^{2+}$ entry to exactly the same amount as Gö6976 (Figure 5B), supporting the mechanism sketched in Figure 5A. Inhibition of LPA-induced $\mathrm{Ca}^{2+}$ entry by CsA is slightly more enhanced than by Gö6976 or FK506 (Figure 5B), supporting the mechanism depicted in Figure 5A further but indicating a crosstalk of CsA with the PI3 kinase-mediated branch of the signaling pathway (see below). Additionally, we tested the effect of FK506 in comparison to Gö6976 treatment in mouse RBCs and TRPC6 ${ }^{-/-}$mouse RBCs (Figure 5C). In both cases, there was no difference between the Gö6976 treatment and that with FK506. Furthermore, for TRPC6 ${ }^{-/-}$RBCs, Gö6976 and FK506, application lacked a significant difference to pure stimulation with $5 \mu \mathrm{M} \mathrm{LPA}$, providing further support for the mechanism presented in Figure 5A.
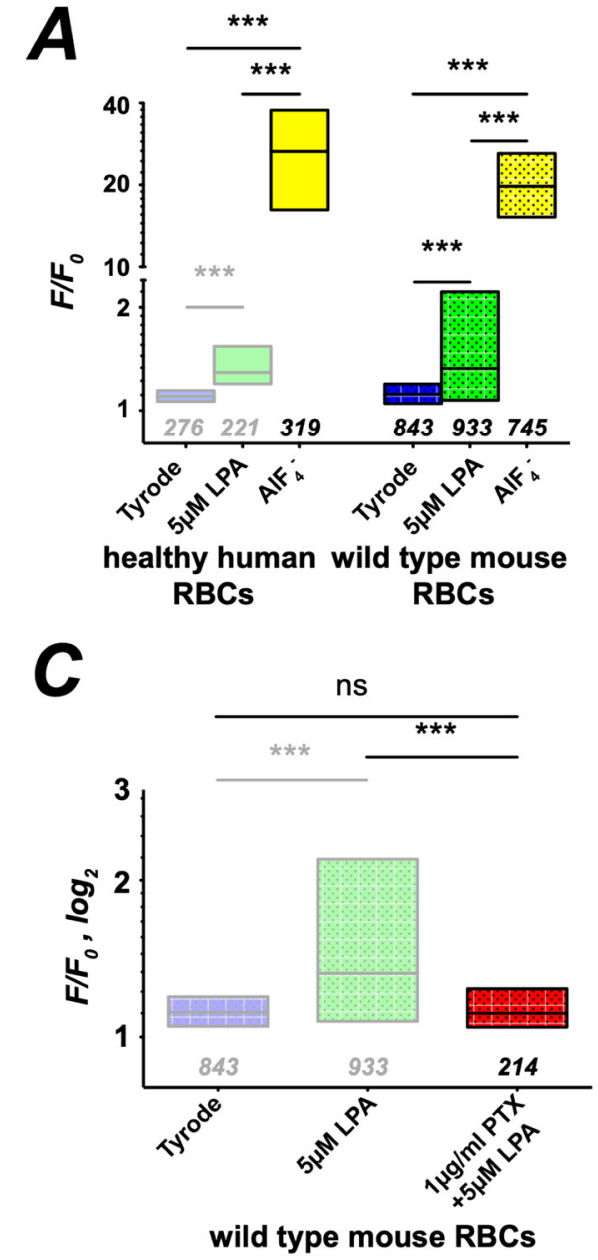

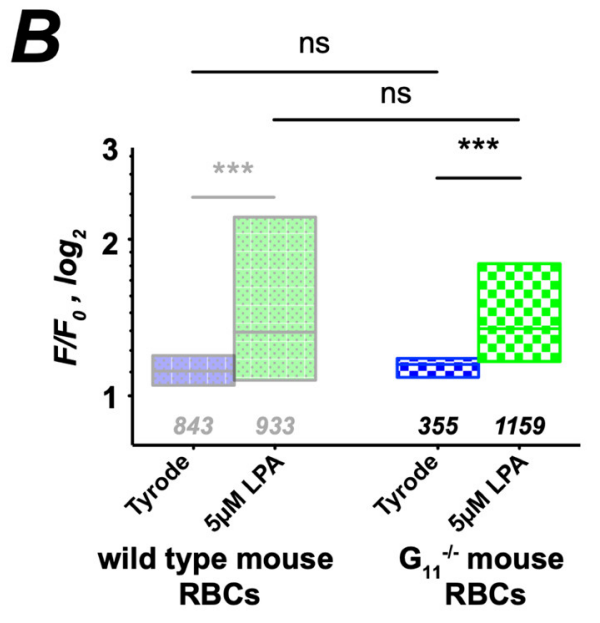

D

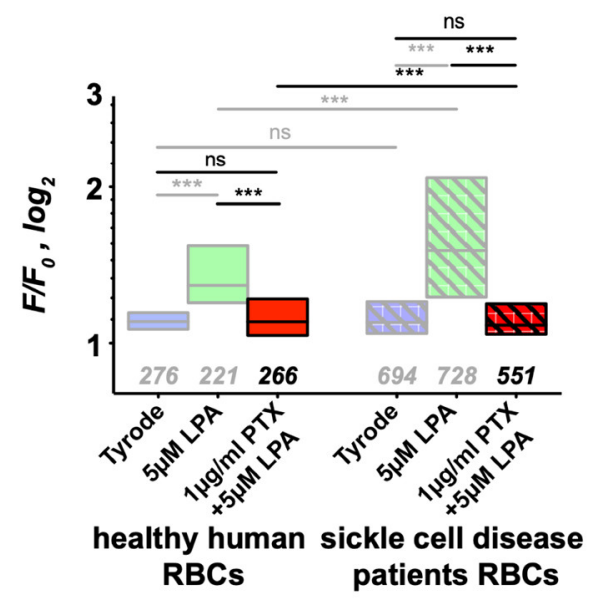

Figure 3. G protein signaling in LPA-induced $\mathrm{Ca}^{2+}$ entry into RBCs. More transparent boxes in the statistics indicate data that are replotted for comparison. All panels present the statistical evaluation, with the numbers below the boxes indicating the number of cells measured. (A) The pan-specific $\mathrm{G}$ protein activator $\mathrm{AlF}_{4}{ }^{-}$induces a Ca ${ }^{2+}$ entry in human and mouse RBCs exceeding the one of LPA stimulation. (B) LPA-induced $\mathrm{Ca}^{2+}$ entry in RBCs of $\mathrm{G} \alpha_{11}$ knock-out mice shows no difference compared to cells of wild-type mice. (C) The $G \alpha_{i}$-specific inhibitor PTX is able to fully block LPA-induced $\mathrm{Ca}^{2+}$ entry in mouse RBCs. (D) LPA stimulation of PTX-pretreated RBCs of healthy donors and sickle cell disease patients. Numbers below the boxes refer to the number of cells analyzed originating from at least three different experiments. ns stands for not significant $(p>0.05)$ and ${ }^{* * *}$ for $p<0.001$. All measurements were performed at room temperature. 

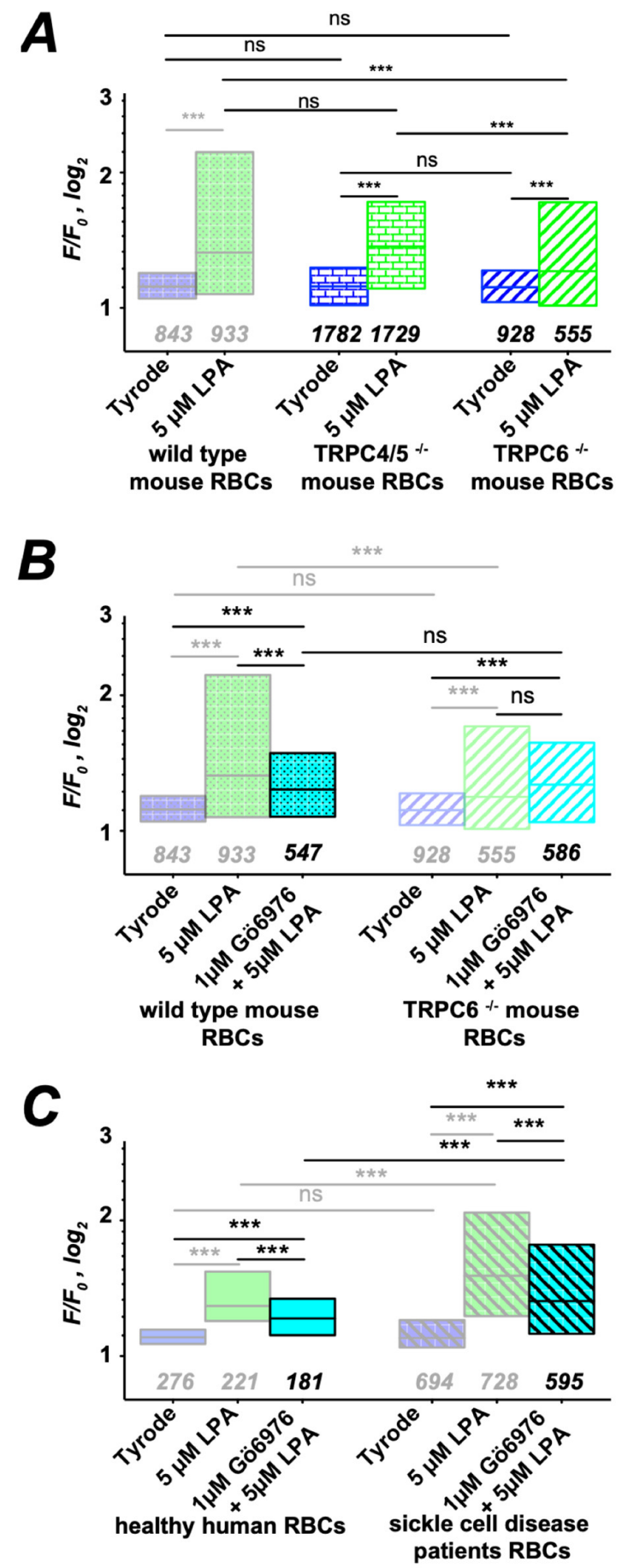

Figure 4. G $\alpha_{i}$ protein signaling activates TRPC6. More transparent boxes indicate data that are replotted for comparison. All panels present the statistical evaluation, with the numbers below the boxes indicating the number of cells measured. (A) LPA stimulation of RBCs from TRPC $4 / 5^{-/-}$ double knock-out and TRPC6 ${ }^{-/-}$mice in comparison to wild-type mice. (B) Gö6976 pretreatment has no effect on the LPA response of TRPC6 ${ }^{-/-} \mathrm{RBC}$ but suppresses $\mathrm{Ca}^{2+}$ entry in RBCs of wildtype mice. (C) Same experiments as in (B) but with RBCs from healthy humans and sickle cell disease patients. Numbers below the boxes refer to the number of cells analyzed originating from at least three different experiments. ns stands for not significant $(p>0.05)$ and ${ }^{* * *}$ for $p<0.001$. All measurements were performed at room temperature. 
A

\section{TRPC6 activation mechanism}

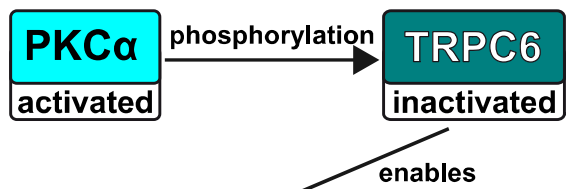

\section{TRPC6 FKPP}

inactivated Calcineurin
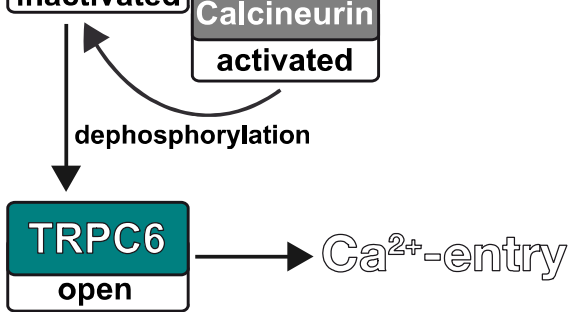

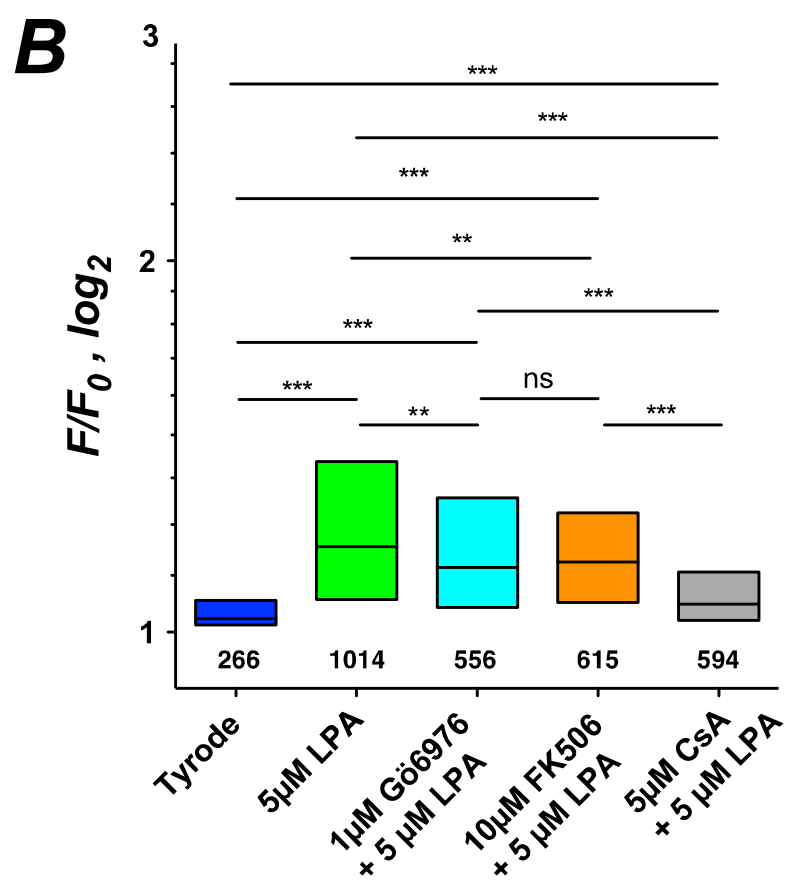

healthy human RBCs

C

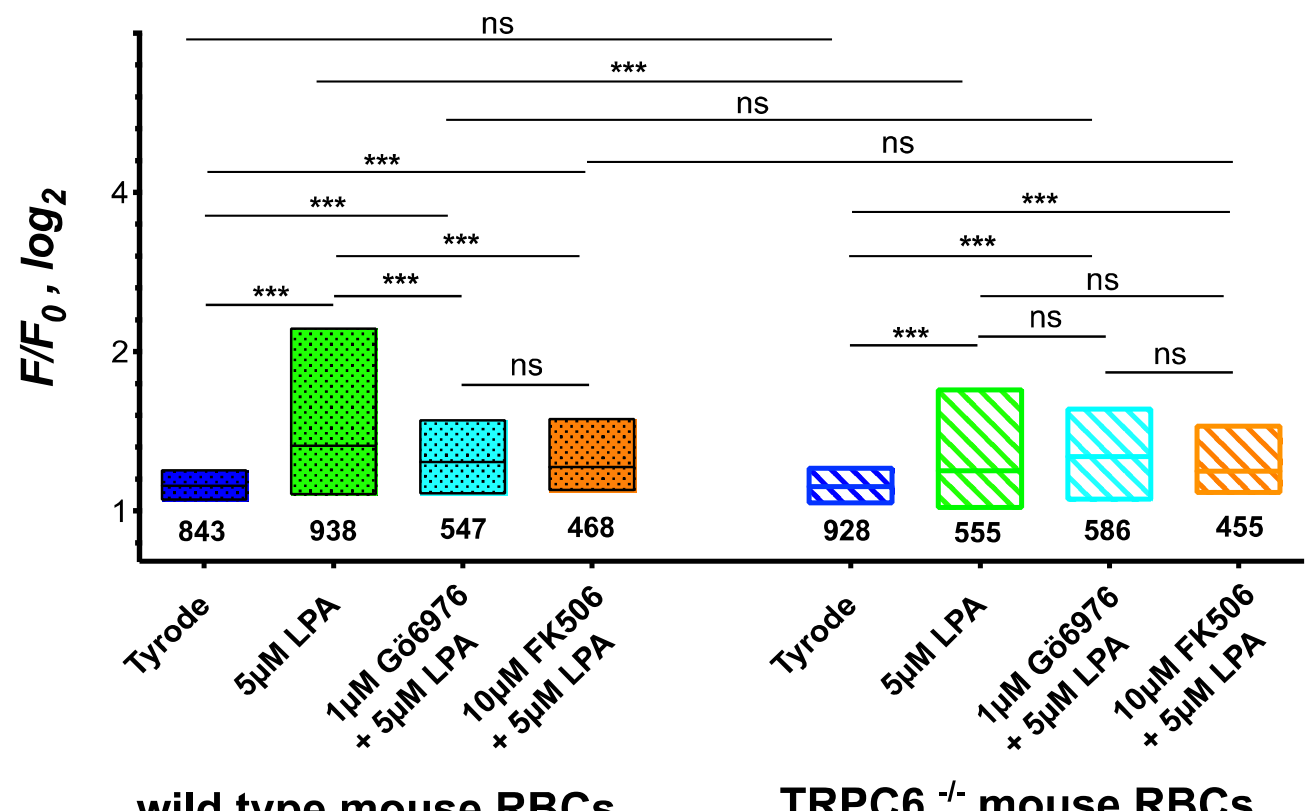

Figure 5. Activation mechanism of TRPC6 by PKC $\alpha$. (A) shows a scheme of the TRPC6 activation mechanism by PKC $\alpha$. (B) presents the statistical evaluation of human RBCs pretreated with Gö6976, FK506 or Cyclosporin A (CsA) followed by LPA stimulation. (C) depicts the statistical evaluation of wild-type mouse RBCs in comparison to RBCs from TRPC6 ${ }^{-/-}$ mice for perfusion with Tyrode (control), $5 \mu \mathrm{M}$ LPA stimulation and $5 \mu \mathrm{M}$ LPA stimulation with pretreatment of $1 \mu \mathrm{M}$ Gö6976 or $10 \mu \mathrm{M}$ FK506. The numbers below the boxes indicate the number of cells measured in at least three different experiments. ns stands for not significant $(p>0.05){ }^{* *}$ for $p<0.01$ and ${ }^{* * *}$ for $p<0.001$. All measurements were performed at room temperature.

\subsection{The MAP Kinase Branch of the Signaling Pathway}

In search of the cause of the remaining amount of $\mathrm{Ca}^{2+}$ entry, we focused on a MAP kinase (MAPK) pathway which was reported to be abundant in RBCs [44]. Therefore, we 
probed RBCs from healthy donors and SCD patients for MAPK activity using an ELISA. Figure 6A depicts the results revealing an increased basal MAPK activity in SCD RBCs.

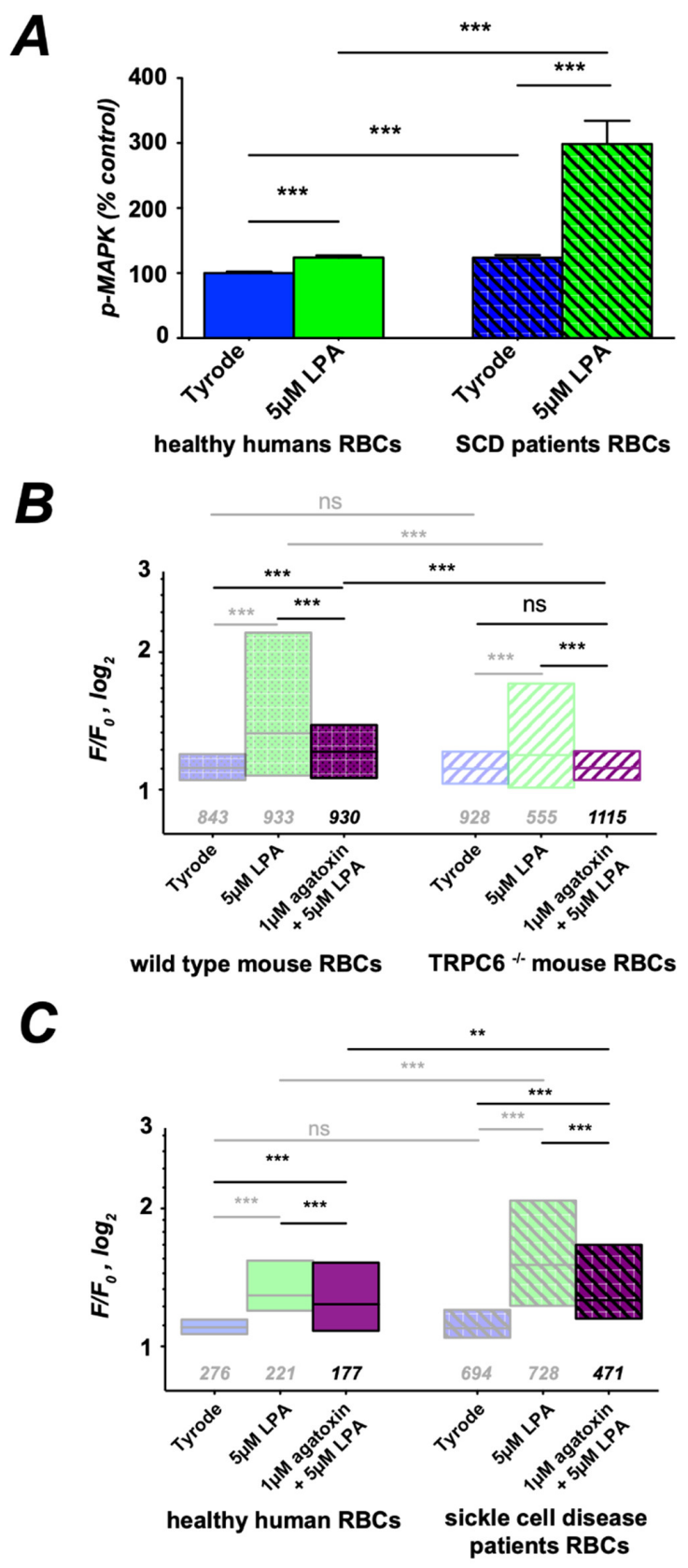

Figure 6. A G $\alpha_{i}$ protein singling activates MAPK and $\omega$-agatoxin-TK-sensitive $\mathrm{Ca}^{2+}$ entry. (A) Phosphorylation assay for MAPK activity by ELISA for RBCs from healthy humans and sickle cell disease patients at rest (Tyrode) and after $15 \mathrm{~min}$ of $5 \mu \mathrm{M}$ LPA stimulation. (B,C) More transparent boxes in the statistics indicate data that are replotted for comparison. $(\mathbf{B}, \mathbf{C})$ present the statistical evaluation, with the numbers below the boxes indicating the number of cells measured. (B) LPA stimulation of RBCs from wild-type and TRPC $6^{-/-}$mice with and without $\omega$-agatoxin-TK pretreatment was followed by fluorescence read out of the $\mathrm{Ca}^{2+}$ fluorophore Fluo-4. (C) Same experiments as in (B) but with RBCs from healthy humans and SCD patients. All measurements were performed at room temperature. ns stands for not significant $(p>0.05),{ }^{* *}$ for $p<0.01$ and ${ }^{* * *}$ for $p<0.001$. All measurements were performed at room temperature. 
LPA induces an increase in MAPK activity, which is more pronounced in RBCs from SCD patients. The $\mathrm{Ca}^{2+}$ channel that is regulated by this signaling pathway is expected to be $\omega$-agatoxin-TK sensitive $[17,24]$. Based on the pharmacology and Western blots of the $\alpha_{1 \mathrm{~A}}$ subunit, this channel was proposed to be $\mathrm{Ca}_{\mathrm{V}} 2.1[17,18]$. We performed the $\mathrm{Ca}^{2+}$-imaging assay of LPA stimulation with and without pre-incubation of $\omega$-agatoxin-TK on RBCs of WT mice and TRPC6 ${ }^{-/}$mice (Figure 6B). $\omega$-agatoxin-TK partly inhibits LPA-induced $\mathrm{Ca}^{2+}$ entry in RBCs from WT mice, whereas in RBCs of $\mathrm{TRPC}^{-/-}$mice, $\omega$-agatoxin-TK keeps internal $\mathrm{Ca}^{2+}$ levels the same as under control conditions.

In human $\mathrm{RBCs}, \mathrm{Ca}^{2+}$ entry upon incubation with $\omega$-agatoxin-TK (Figure $6 \mathrm{C}$ ) is qualitatively the same as in wild-type mouse RBCs (Figure 6B). In RBCs of SCD patients, the $\mathrm{Ca}^{2+}$ response to LPA upon incubation with $\omega$-agatoxin-TK is increased compared to healthy donors (Figure 6C).

The results presented in Figure 6B,C point to an involvement of the Cav2.1 channel that was shown to be present in RBCs [18]. On first view, it seems odd that a voltagegated channel could be activated in non-excitable RBCs. However, we have developed a concept that is based on the activation of the Gárdos channel $\left(\mathrm{Ca}^{2+}\right.$-activated $\mathrm{K}^{+}$channel, $\mathrm{KCNN} 4, \mathrm{~K}_{\mathrm{Ca}} 3.1$ ), which leads to $\mathrm{RBC}$ hyperpolarization from $-10 \mathrm{mV}$ to approximately $-70 \mathrm{mV}$ [45]. We recently provided experimental evidence for this hypothesis [46]. The main idea is summarized in Figure 7A.
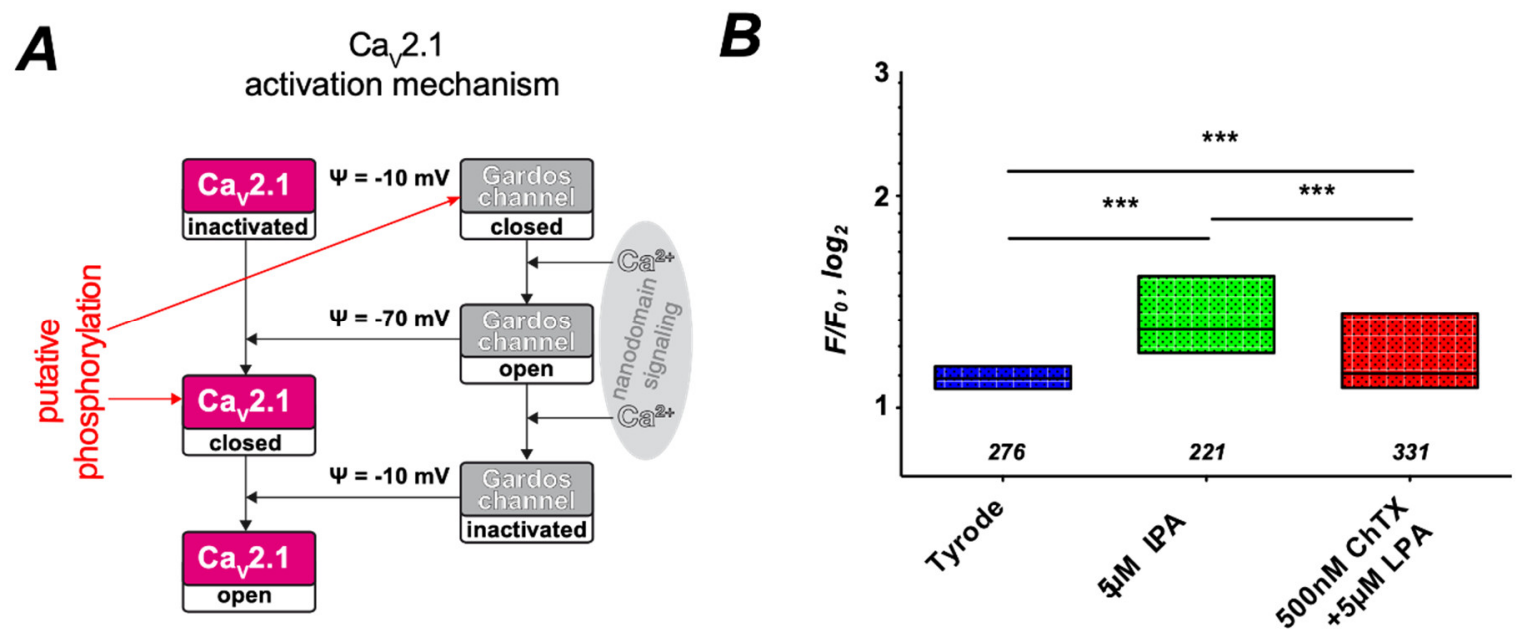

Figure 7. Activation mechanism of $\mathrm{Ca}_{\mathrm{V}} 2.1$ by the Gárdos channel. (A) shows a scheme of the Cav 2.1 activation mechanism involving the Gárdos channel. (B) presents the statistical evaluation of RBCs pretreated with the Gárdos channel inhibitor Charybdotoxin (ChTX) followed by LPA stimulation, with the numbers below the boxes indicating the number of cells measured in at least three different experiments. ${ }^{* * *}$ stands for $p<0.001$. All measurements were performed at room temperature.

The data presented in Figure 6 indicate that kinase activity favors the channel opening. It is unclear whether the Gárdos channel or $\mathrm{Cav}_{\mathrm{v}} 2.1$ is phosphorylated. Both channels contain numerous putative phosphorylation sites. Although we kept both options in the scheme of Figure 7A, we favor the phosphorylation of the Gárdos channel, which makes more sense conceptionally and was also reported to occur in neurons [47].

If indeed the Gárdos channel is involved in the activation of $\mathrm{Ca}_{V} 2.1$, inhibition of the Gárdos channel should have an impact on LPA-induced $\mathrm{Ca}^{2+}$ entry. The result of this experiment is depicted in Figure $7 \mathrm{~B}$ and indeed shows a significantly lower $\mathrm{Ca}^{2+}$ level when the LPA stimulation is performed in the presence of $500 \mathrm{nM}$ of the Gárdos channel inhibitor Charybdotoxin (ChTX). To complement the approach presented in Figure 6, we performed further pharmacological investigations and pre-incubated the RBCs with U0126, an inhibitor of MEK [48], the upstream activator of MAPK, as well as with Wortmannin (WTM) a phosphoinositide 3 kinase (PI3 kinase) inhibitor [49]. Both substances showed 
basically the same effect (Figure 8). Figure $8 \mathrm{~A}$ reveals a suppression of LPA-induced $\mathrm{Ca}^{2+}$ entry by the pharmacological interventions in wild-type RBCs, while in TRPC $6^{-/-}$RBCs, $\mathrm{Ca}^{2+}$ entry is completely abolished. In human RBCs, $\mathrm{Ca}^{2+}$ entry upon incubation with the blocking agents (Figure $8 \mathrm{~B}$ ) is qualitatively the same as in wild-type mouse RBCs (Figure 8A). In RBCs of SCD patients, the $\mathrm{Ca}^{2+}$ response to LPA upon incubation with WTM and U0126 is upscaled compared to healthy donors (Figure 8B).

\subsection{The Overview of the Signaling Cascade}

After identifying the two signaling branches, the remaining question is whether the two branches completely account for the total LPA-induced $\mathrm{Ca}^{2+}$ entry in RBCs. The experiments with the TRPC $6^{-1-}$ mouse RBCs in Figures $6 \mathrm{~B}$ and $8 \mathrm{~A}$ already point in this direction. The experiments depicted in Figure $8 \mathrm{C}$ provide further evidence that the two branches of the pathway, the PKC $\alpha$ mediated (blocked by Gö6976) and the PI3 kinase activated (blocked by WTM), can completely explain LPA-induced $\mathrm{Ca}^{2+}$ entry into RBCs of healthy humans, sickle cell disease patients and mice.

A schematic overview of the signaling cascade is given in Figure 9A. Here it becomes evident that both branches of the signaling cascade require $\mathrm{Ca}^{2+}$ to be activated. The PKC branch needs $\mathrm{Ca}^{2+}$ to activate PKC $\alpha[50]$ and the MAP kinase branch requires $\mathrm{Ca}^{2+}$ to activate the Gárdos channel [11]. One could argue that both pathways stimulate each other by positive feedback loops, but also one branch operates if the other one is inhibited, as shown in Figures 6B and 8.

Both in vivo as well as in our in vitro experiments, RBCs experience a certain shear stress. In vivo, this is almost obvious and there it results in a measurable $\mathrm{Ca}^{2+}$ increase [51] most probably mediated by the mechanosensitive channel Piezo1, which is abundant in RBCs [52-54]. In our in vitro experiments, we used a gravity-driven local perfusion system, which results in a very moderate shear stress applied to the cells in the field of view in the microscope, which is much below physiological levels (0.3-10 Pa) in vivo. However, this flow/shear stress occurs in all experiments also under control conditions, when only Tyrode is perfused. Having a closer look at these control experiments (Figure $1 \mathrm{Ad}, \mathrm{C}$ ), the $\mathrm{Ca}^{2+}$ does not remain constant (self-ratio $\mathrm{F} / \mathrm{F}_{\mathrm{o}}$ of 1 ) but slightly increases. Therefore, a small fractional $\mathrm{Ca}^{2+}$ entry by a mechanosensitive channel such as Piezo1 could be the $\mathrm{Ca}^{2+}$ source enabling both branches of the signaling cascade.

To test this hypothesis, we performed experiments on human RBCs, where the $5 \mu \mathrm{M}$ LPA were applied (i) without perfusion (less exact time point of application) and (ii) in the presence of $2 \mu \mathrm{M}$ of the mechanosensitive channel inhibitor GsMTx-4 [55]. The results are presented in Figure 9B and reveal that indeed LPA-induced $\mathrm{Ca}^{2+}$ entry could be prevented under both additional conditions tested, supporting the hypothesis that a mechanosensitive channel such as Piezo1 provides fractional $\mathrm{Ca}^{2+}$ entry, enabling the signaling cascades as outlined in Figure 9A. 


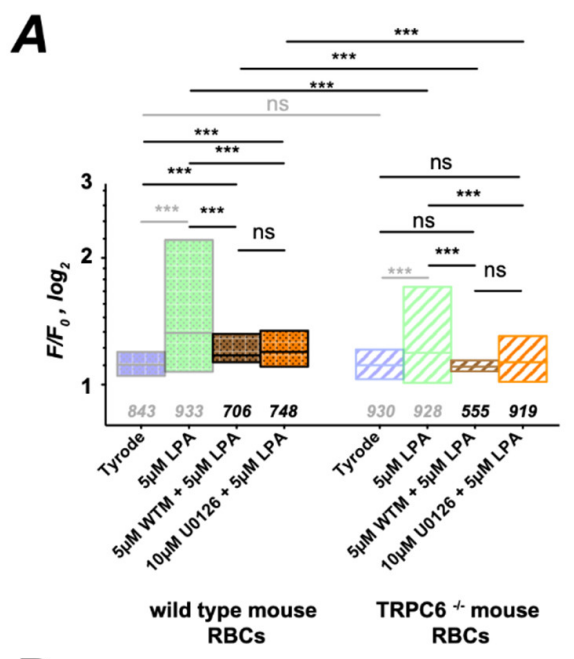

B
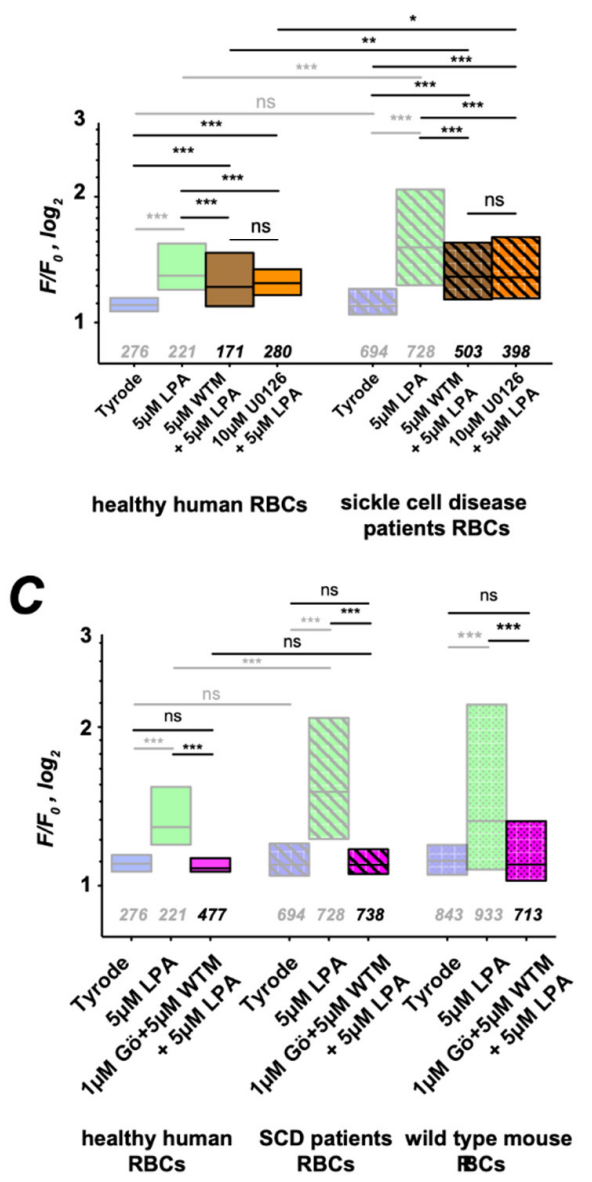

Figure 8. The MAPK-associated pathway. More transparent boxes in the statistics indicate data that are replotted for comparison. All panels present the statistical evaluation, with the numbers below the boxes indicating the number of cells measured. (A) LPA stimulation of RBCs from wild-type and TRPC $6^{-/-}$mice after pretreatment with Wortmannin or U0126 was followed by fluorescence read out of the $\mathrm{Ca}^{2+}$ fluorophore Fluo-4. (B) Same experiments as in (A) but with RBCs from healthy humans and sickle cell disease patients. (C) shows the statistical evaluation of RBCs pretreated with Gö6976 and Wortmannin followed by LPA stimulation. All measurements were performed at room temperature. ns stands for not significant $(p>0.05){ }^{*}$ for $p<0.05,{ }^{* *}$ for $p<0.01$ and ${ }^{* * *}$ for $p<0.001$. 

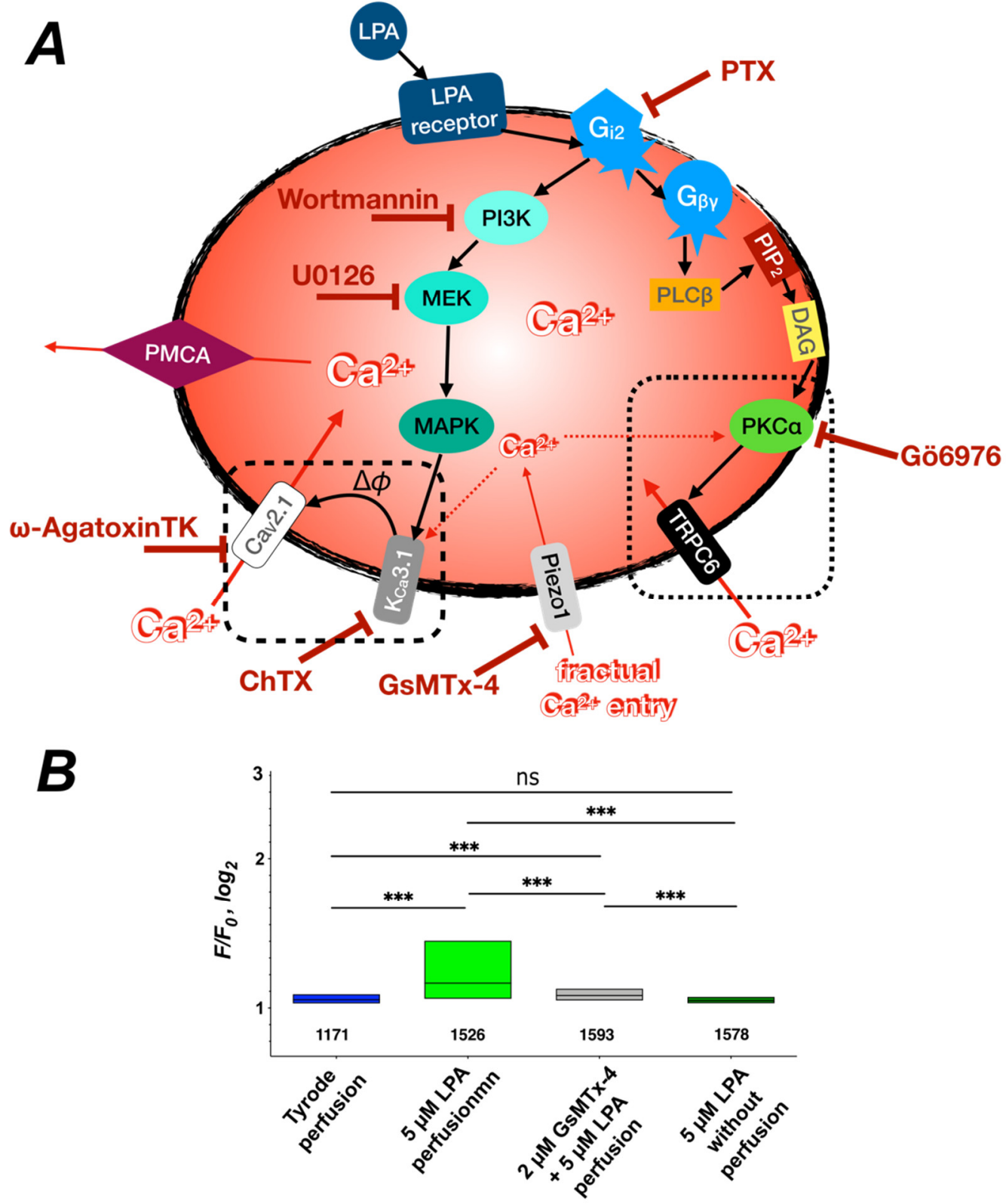

Figure 9. Overview of the $\mathrm{Ca}^{2+}$ signaling cascade. (A) shows a scheme of the hypothesized $\mathrm{Ca}^{2+}$ signaling cascade based on the indications presented in this paper. It includes the pharmacological tools (inhibitors) used to probe the RBCs (dark red). The cascade starts with LPA stimulation of LPA receptors as outlined in Figures 1 and 2. G protein signaling was shown in Figure 3. The involvement of PKC $\alpha$ and TRPC6 in one of the signaling branches was indicated in Figure 4 . PKC $\alpha$ is generally activated through the involvement of phospholipase $\mathrm{C}_{\beta}$ (PLC $\beta$ ), phosphatidylinositol-4,5-bisphosphate (PIP 2 ) and diacylglycerol (DAG) [56]. The detailed activation of TRPC6 by PKC $\alpha$ (black dotted box) is shown in Figure 5A. The second signaling branch involving PI3 kinase (PI3K), MEP, MAP kinase (MAPK) and Cav2.1 was explored in Figures 6-8, whereas the detailed interaction between $\mathrm{Ca}_{\mathrm{V}} 2.1$ and the Gárdos channel (black dashed box) is detailed in Figure 7A. Indications for a fractual $\mathrm{Ca}^{2+}$ signaling by a mechanosensitive ion channel are provided in (B). Piezo1 as indicated by the scheme is only an example for a mechanosensitive channel. The plasma membrane $\mathrm{Ca}^{2+}$ pump (PMCA) was not investigated within this paper but since it is the major transport mechanism of $\mathrm{Ca}^{2+}$ out of the $\mathrm{RBC}$, it was added to complete the overall picture. (B) presents the statistical evaluation of human RBCs pretreated with the inhibitor of mechanosensitive channels, GsMTx-4, followed by LPA stimulation, with the numbers below the boxes indicating the number of cells measured in at least three different experiments. In contrast to all other experiments, for the measurement of the grey bar, no local perfusion system was used to completely avoid any shear stress to the cells. ns stands for $p<0.05$ and ${ }^{* *}$ for $p<0.001$. All measurements were performed at room temperature. 


\section{Discussion}

When judging the results, we like to point out that RBCs are very special cells and although much of our current knowledge of membrane transport originates from RBCs when they have been 'the' model cell for membrane transport during the last century [57], they lack a number of mechanisms. First of all, there is the lack of organelles in mammalian RBCs, i.e., they do not contain cell internal ion stores, a property which favored them as model cells. Consequently, well-known processes such as $\mathrm{Ca}^{2+}$-induced $\mathrm{Ca}^{2+}$ release or store-operated $\mathrm{Ca}^{2+}$ channels do not exist in RBCs. Furthermore, it is worthwhile to mention that mature mammalian RBCs do not contain translational machinery, i.e., they have the set of proteins from when the erythroblasts enucleated and the RBCs were released into the circulation. Depending on the aging process of the particular proteins, young and old RBCs contain different sets of proteins [58], i.e., receptor, ion channel and kinase content, just to name a few proteins, vary during the RBC lifetime of in average approximately 115 days in humans [59] and 45 days in mice [60]. Additionally, the number of ion channel copies is very low in RBCs-for the Gárdos channel, an estimated 1-5 copies per cell in 75\% of the cells [61,62], and Piezo1 and TRPC6 are also within the detection limit [63]. Therefore, functional measurements, especially when they integrate the signal as in $\mathrm{Ca}^{2+}$-imaging experiments, are more sensitive than molecular biological approaches.

\subsection{Elucidating the Signaling Mechanism of LPA-Induced $\mathrm{Ca}^{2+}$ Entry in RBCS}

Our results show that $\mathrm{Ca}^{2+}$ uptake evoked by LPA stimulation and well described in healthy RBCs $[4,6,17,21,30]$ is markedly increased in SCD (Figure 1). As the molecular mechanisms of LPA-induced $\mathrm{Ca}^{2+}$ influx are so far unknown, we aimed at elucidating the various steps in the signaling cascade in healthy RBCs and compared it with pathological RBCs. By using Western blot and immunocytochemistry, we first probed for LPA receptors and found that whereas the same isoforms $(1,2$ and 4$)$ were expressed in both populations, LPA receptor type 4 was augmented more than 3 -fold in SCD RBCs (Figure 2). The increase in $\mathrm{Ca}^{2+}$ influx in both cell populations was conveyed by two branches of a signaling pathway starting at an LPA receptor and the further activation of a $\mathrm{G} \alpha_{i}$ protein (Figure 3). It is worthwhile to mention that full activation of $\mathrm{G}$ proteins by $\mathrm{AlF}_{4}{ }^{-}$exceeds by far the $G \alpha_{i}$ activation by LPA receptors (Figure 3A), confirming the abundance of various $\mathrm{G}$ proteins in RBCs [64]. One branch of the signaling pathway regulated the TRPC6 channel through recruitment of PKC $\alpha$ (Figures 4 and 5), whereas the other points to the opening of the $\mathrm{Ca}_{\mathrm{V}} 2.1$ channel involving PI3, MEK and MAP kinases and the stochastic activity of the Gárdos channel (Figures 6-8). The suggested signaling is heavily based on experimental evidence from experiments with knock-out mice (Figures 3-8). Although this genetic-based approach cannot be directly transferred to human RBCs, a number of pharmacological studies, which show a high functional homology between mouse and human RBCs (Figures 3-8), suggest a projection of the signaling cascade (Figure 9A) to humans.

\subsection{LPA Signaling in RBCs of Sickle Cell Disease Patients}

The cause of the increased $\mathrm{Ca}^{2+}$ response of SCD RBCs presumably is at least partially the LPA receptor 4, whose abundance compared to healthy cells acts as an amplifying switch for the entire signaling cascade. We hypothesize that the increased density of particular receptors might be a general feature of sickle cells. This notion is supported by the fact that NMDA receptors also show a higher abundance in sickle cells compared to healthy RBCs [65]. One of the reasons behind this resides in the average age of SCD RBCs (average lifetime of 10-20 days [66]) compared to healthy RBCs (average lifetime of approximately 115 days [59]), and since RBCs do not produce new proteins, receptors are lost over time.

The LPA signaling pathway and the consecutive activation of channels as well as the discovery of NMDA receptors in RBCs [13] place $\mathrm{Ca}^{2+}$ channels in focus as pharmaceutical targets for the treatment of one of the most severe symptoms of SCD, i.e., VOC. This holds 
particular true, as $\mathrm{Ca}^{2+}$ has been identified as a trigger for $\mathrm{RBC}$ self-aggregation $[6,22,67]$ and for their adhesion to endothelial cells [68-70].

\subsection{Potential for Heterogeneity}

Recently, direct channel activation of LPA in RBC was discussed [4,6]. However, tremendous heterogeneity in the LPA response of the RBCs of each donor $[16,17,30]$ (cp. also Figure $1 \mathrm{Ac}, \mathrm{Bc}$ ) could not be comprehensively explained by RBC age [30,71]. In light of the current results revealing a substantial signaling cascade with numerous directly involved molecular players, this provides a potential chain where each individual link may cause a modulation of the final $\mathrm{Ca}^{2+}$ signal. This variety of direct players is supplemented by a presumably varying contribution of indirect modulators, particularly the plasma membrane $\mathrm{Ca}^{2+}$ ATPase (PMCA) [72], which is activated by $60-100 \mathrm{nM} \mathrm{Ca}^{2+}$ [73] and may directly pump out the $\mathrm{Ca}^{2+}$ which enters the RBCs, and its activity will depend on the metabolic status of the RBC, which can vary from cell to cell.

\subsection{Novel Molecular Interactions}

Although the abundance of $G \alpha_{i}$ protein is well documented in RBCs [74,75], this is, to our knowledge, the first report of a $\mathrm{G} \alpha_{\mathrm{i}}-\mathrm{PKC} \alpha$ interaction in RBCs. However, for platelets, such a signaling step has been previously reported [76]. Data on the interaction of PKC and TRPC6 are rather scarce and mostly show suppression of TRPC6 expression by PKC $[77,78]$, which is irrelevant to the fast changes induced by PKC $\alpha$ in the TRPC6 channel in RBCs, leading to an acute increase in the $\mathrm{Ca}^{2+}$ influx within minutes. Direct interaction (phosphorylation) of TRPC6 by PKC is still controversial $[42,79,80]$. However, relying on single-channel recordings, in coronary artery smooth muscle cells, an inhibition of TRPC 6 by inhibition of PKC was reported [81] — similar to what we found in RBCs.

Activation of a PI3 kinase/MAP kinase pathway by $\mathrm{G} \alpha \alpha_{\mathrm{i}}$ has already been described in the context of platelets $[82,83]$. The pharmacological inhibition of LPA-induced $\mathrm{Ca}^{2+}$ entry in TRPC $6^{-/-}$RBCs using $\omega$-agatoxin-TK (Figure $6 \mathrm{~B}$ ) provides clear evidence for the involvement of $\mathrm{Ca}_{\mathrm{V}} 2.1$ in the proposed signaling cascade. Although the modulation of voltage-activated $\mathrm{Ca}^{2+}$ channels by $\mathrm{G}$ protein-induced signaling has been reported [84], the abundance and operation of voltage-gated channels in non-excitable cells is anything but established. Even though such discussions were performed in the context of T lymphocytes, where the expression and function of voltage-gated $\mathrm{Ca}^{2+}$ channels have been shown [85-87], our interpretation follows the idea of hyperpolarization-depolarization jumps caused by fluctuations in Gárdos channel activity. This hypothesis was previously published [45], and recently supported with experimental evidence [46]. In the present paper, we were able to add experimental evidence: when the $\mathrm{K}^{+}$-conducting Gárdos channel was blocked, LPA-induced $\mathrm{Ca}^{2+}$ entry was also diminished (Figure 7B) - to a similar extent as observed with modulation by the Cav2.1 channel inhibitor $\omega$-agatoxin-TK (Figure 6C). We have to admit that this concept only works because (i) the number of Gárdos channels in RBCs is very low $[61,62]$ and (ii) we face the situation of a submaximal Gárdos channel activation. As a consequence the probability of the Gárdos channels opening leads to stochastic opening and closing, which enables membrane potential flickering. Such depolarizationhyperpolarization cycles are required for the activation of a voltage-gated channel.

\section{Conclusions}

We found a new $\mathrm{Ca}^{2+}$ signaling cascade that is increased in RBCs of SCD patients in the first place by an increased occurrence of the LPA receptor 4 . However, since $G_{i}$ protein signaling triggers an entire signaling cascade, we provide a set of new pharmacological targets that might be promising in addressing the most severe symptom of SCD, i.e., VOC.

Supplementary Materials: The following are available online at https:/ /www.mdpi.com/2073-440 9/10/2/456/s1, Figure S1: Gel electrophoresis analysis of LPA receptors 1-5 in human red blood cells (RBCs) of healthy donors and sickle cell disease (SCD) patients; Figure S2: Testing the reported TRPC6 inhibitors larixyl acetate and SAR7334. 
Author Contributions: Conceptualization, L.K.; methodology, J.W., L.H. and S.R.; formal analysis, J.W., L.H., P.C. and L.K.; investigation, J.W. and L.H.; resources, W.E.N., P.C., J.S.G., A.B., L.B. and L.K.; data curation, J.W., L.H., S.R., L.B. and L.K.; writing-original draft preparation, J.W. and L.K.; writing-review and editing, all authors; visualization, J.W., L.H. and L.K.; supervision, S.R. and L.K.; project administration, W.E.N., A.B. and L.K.; funding acquisition, W.E.N., P.C., A.B., L.B. and L.K. All authors have read and agreed to the published version of the manuscript.

Funding: This study was supported by the European Framework Horizon 2020 under grant agreement number 860436 (EVIDENCE) and by the Intramural Research Program of the NIH (Project Z01-ES101643). Furthermore, we acknowledge support by the Deutsche Forschungsgemeinschaft (DFG, German Research Foundation) and Saarland University within the funding programme Open Access Publishing.

Institutional Review Board Statement: The study was conducted according to the guidelines of the Declaration of Helsinki, and approved by the 'Ärztekammer des Saarlandes' under registration number 132/08 for healthy donors and by the Canton Zürich ethics committee under registration number KEK ZH NR 2010-0237 as well as by the regional ethics committee CPP Sud/Ouest Outre Mer III, Bordeaux under registration number 2010-A00244-35 for SCD patients.

Informed Consent Statement: In all cases, blood donors provided their written informed consent to participate in this study. This consent procedure was approved by the respective ethics committees under the above-mentioned study registration numbers.

Data Availability Statement: The data presented in this study are available on request from the corresponding author. The data are not publicly available due to privacy restrictions.

Acknowledgments: The authors like to thank P. Weissgerber and the Transgene Unit of the SPF animal facility of the Medical Faculty of Saarland University for taking care of the mice and P. Lipp for providing the laboratory for the imaging experiments.

Conflicts of Interest: The authors declare no conflict of interest. The funders had no role in the design of the study; in the collection, analyses, or interpretation of data; in the writing of the manuscript, or in the decision to publish the results.

\section{References}

1. Lew, V.L.; Tsien, R.Y.; Miner, C.; Bookchin, R.M. Physiological $\left[\mathrm{Ca}^{2+}\right]$ i Level and Pump-Leak Turnover in Intact Red Cells Measured Using an Incorporated Ca Chelator. Nature 1982, 298, 478-481. [CrossRef]

2. Etzion, Z.; Tiffert, T.; Bookchin, R.M.; Lew, V.L. Effects of Deoxygenation on Active and Passive Ca ${ }^{2+}$ Transport and on the Cytoplasmic $\mathrm{Ca}^{2+}$ Levels of Sickle Cell Anemia Red Cells. J. Clin. Investig. 1993, 92, 2489-2498. [CrossRef]

3. Kaestner, L.; Bianchi, P. Trends in the Development of Diagnostic Tools for Red Blood Cell-Related Diseases and Anemias. Front. Physiol. 2020, 11, 387. [CrossRef]

4. Nguyen, D.B.; Wagner-Britz, L.; Maia, S.; Steffen, P.; Wagner, C.; Kaestner, L.; Bernhardt, I. Regulation of Phosphatidylserine Exposure in Red Blood Cells. Cell Physiol. Biochem. 2011, 28, 847-856. [CrossRef] [PubMed]

5. Weiss, E.; Rees, D.C.; Gibson, J.S. Role of Calcium in Phosphatidylserine Externalisation in Red Blood Cells from Sickle Cell Patients. Anemia 2011, 2011, 379894. [CrossRef]

6. Steffen, P.; Jung, A.; Nguyen, D.B.; Müller, T.; Bernhardt, I.; Kaestner, L.; Wagner, C. Stimulation of Human Red Blood Cells Leads to $\mathrm{Ca}^{2+}$-Mediated Intercellular Adhesion. Cell Calcium 2011, 50, 54-61. [CrossRef]

7. Bogdanova, A.; Makhro, A.; Wang, J.; Lipp, P.; Kaestner, L. Calcium in Red Blood Cells-a Perilous Balance. Int. J. Mol. Sci. 2013, 14, 9848-9872. [CrossRef] [PubMed]

8. Lew, V.L.; Ortiz, O.E.; Bookchin, R.M. Stochastic Nature and Red Cell Population Distribution of the Sickling-Induced Ca ${ }^{2+}$ Permeability. J. Clin. Investig. 1997, 99, 2727-2735. [CrossRef]

9. Browning, J.; Robinson, H.; Ellory, C.; Gibson, J. Deoxygenation-Induced Non-Electrolyte Pathway in Red Cells from Sickle Cell Patients. Cell Physiol. Biochem. 2007, 19, 165-174. [CrossRef]

10. Browning, J.A.; Staines, H.M.; Robinson, H.C.; Powell, T.; Ellory, J.C.; Gibson, J.S. The Effect of Deoxygenation on Whole-Cell Conductance of Red Blood Cells from Healthy Individuals and Patients with Sickle Cell Disease. Blood 2007, 109, 2622-2629. [CrossRef]

11. Kaestner, L.; Bogdanova, A.; Egee, S. Calcium Channels and Calcium-Regulated Channels in Human Red Blood Cells. Adv. Exp. Med. Biol. 2020, 1131, 625-648. [CrossRef]

12. Hänggi, P.; Makhro, A.; Gassmann, M.; Schmugge, M.; Goede, J.S.; Speer, O.; Bogdanova, A. Red Blood Cells of Sickle Cell Disease Patients Exhibit Abnormally High Abundance of N-methyl D-aspartate Receptors Mediating Excessive Calcium Uptake. Brit. J. Haematol. 2014, 167, 252-264. [CrossRef] 
13. Makhro, A.; Hänggi, P.; Goede, J.S.; Wang, J.; Brüggemann, A.; Gassmann, M.; Schmugge, M.; Kaestner, L.; Speer, O.; Bogdanova, A. N-Methyl-d-Aspartate Receptors in Human Erythroid Precursor Cells and in Circulating Red Blood Cells Contribute to the Intracellular Calcium Regulation. Am. J. Physiol. Cell Physiol. 2013, 305, C1123-C1138. [CrossRef]

14. Hegemann, I.; Sasselli, C.; Valeri, F.; Makhro, A.; Müller, R.; Bogdanova, A.; Manz, M.G.; Gassmann, M.; Goede, J.S. MEMSID: Results From a Phase 2 Pilot Study on Memantine Treatment for Sickle Cell Disease. Hemasphere 2020, 4, e452. [CrossRef] [PubMed]

15. Mahkro, A.; Hegemann, I.; Seiler, E.; Simionato, G.; Claveria, V.; Bogdanov, N.; Sasselli, C.; Torgerson, P.; Kaestner, L.; Manz, M.G.; et al. A Pilot Clinical Phase II Trial MemSID: Acute and Durable Changes of Red Blood Cells of Sickle Cell Disease Patients on Memantine Treatment. Ejhaem 2020, 1, 23-34. [CrossRef]

16. Kaestner, L.; Tabellion, W.; Weiss, E.; Bernhardt, I.; Lipp, P. Calcium Imaging of Individual Erythrocytes: Problems and Approaches. Cell Calcium 2006, 39, 13-19. [CrossRef] [PubMed]

17. Yang, L.; Andrews, D.A.; Low, P.S. Lysophosphatidic Acid Opens a Ca(++) Channel in Human Erythrocytes. Blood 2000, 95, 2420-2425. [CrossRef]

18. Andrews, D.A.; Yang, L.; Low, P.S. Phorbol Ester Stimulates a Protein Kinase C-Mediated Agatoxin-TK-Sensitive Calcium Permeability Pathway in Human Red Blood Cells. Blood 2002, 100, 3392-3399. [CrossRef] [PubMed]

19. Kaestner, L.; Christophersen, P.; Bernhardt, I.; Bennekou, P. The Non-Selective Voltage-Activated Cation Channel in the Human Red Blood Cell Membrane: Reconciliation between Two Conflicting Reports and Further Characterisation. Bioelectrochemistry 2000, 52, 117-125. [CrossRef]

20. Kaestner, L.; Bernhardt, I. Ion Channels in the Human Red Blood Cell Membrane: Their Further Investigation and Physiological Relevance. Bioelectrochemistry 2002, 55, 71-74. [CrossRef]

21. Chung, S.M.; Bae, O.N.; Lim, K.M.; Noh, J.Y.; Lee, M.Y.; Jung, Y.S.; Chung, J.H. Lysophosphatidic Acid Induces Thrombogenic Activity through Phosphatidylserine Exposure and Procoagulant Microvesicle Generation in Human Erythrocytes. Arterioscler. Thromb. Vasc. Biol. 2007, 27, 414-421. [CrossRef]

22. Kaestner, L.; Steffen, P.; Nguyen, D.B.; Wang, J.; Wagner-Britz, L.; Jung, A.; Wagner, C.; Bernhardt, I. Lysophosphatidic Acid Induced Red Blood Cell Aggregation in Vitro. Bioelectrochemistry 2012, 87, 89-95. [CrossRef]

23. Wesseling, M.C.; Wagner-Britz, L.; Nguyen, D.B.; Asanidze, S.; Mutua, J.; Mohamed, N.; Hanf, B.; Ghashghaeinia, M.; Kaestner, L.; Bernhardt, I. Novel Insights in the Regulation of Phosphatidylserine Exposure in Human Red Blood Cells. Cell Physiol. Biochem. 2016, 39, 1941-1954. [CrossRef] [PubMed]

24. Wagner-Britz, L.; Wang, J.; Kaestner, L.; Bernhardt, I. Protein Kinase Ca and P-Type Ca 2+ Channel Ca V 2.1 in Red Blood Cell Calcium Signalling. Cell Physiol. Biochem. 2013, 31, 883-891. [CrossRef]

25. Govekar, R.B.; Zingde, S.M. Protein Kinase C Isoforms in Human Erythrocytes. Ann. Hematol. 2001, 80, 531-534. [CrossRef] [PubMed]

26. Stea, A.; Soong, T.W.; Snutch, T.P. Determinants of PKC-Dependent Modulation of a Family of Neuronal Calcium Channels. Neuron 1995, 15, 929-940. [CrossRef]

27. Minetti, G.; Egée, S.; Mörsdorf, D.; Steffen, P.; Makhro, A.; Achilli, C.; Ciana, A.; Wang, J.; Bouyer, G.; Bernhardt, I.; et al. Red Cell Investigations: Art and Artefacts. Blood Rev. 2013, 27, 91-101. [CrossRef]

28. Scheller, N.; Resa-Infante, P.; de la Luna, S.; Galao, R.P.; Albrecht, M.; Kaestner, L.; Lipp, P.; Lengauer, T.; Meyerhans, A.; Díez, J. Identification of PatL1, a Human Homolog to Yeast P Body Component Pat1. Biochim. Biophys. Acta 2007, 1773, 1786-1792. [CrossRef] [PubMed]

29. Tian, Q.; Pahlavan, S.; Oleinikow, K.; Jung, J.; Ruppenthal, S.; Scholz, A.; Schumann, C.; Kraegeloh, A.; Oberhofer, M.; Lipp, P.; et al. Functional and Morphological Preservation of Adult Ventricular Myocytes in Culture by Sub-Micromolar Cytochalasin D Supplement. J. Mol. Cell Cardiol. 2012, 52, 113-124. [CrossRef]

30. Wang, J.; Wagner-Britz, L.; Bogdanova, A.; Ruppenthal, S.; Wiesen, K.; Kaiser, E.; Tian, Q.; Krause, E.; Bernhardt, I.; Lipp, P.; et al. Morphologically Homogeneous Red Blood Cells Present a Heterogeneous Response to Hormonal Stimulation. PLoS ONE 2013, 8, e67697. [CrossRef]

31. Choi, J.W.; Herr, D.R.; Noguchi, K.; Yung, Y.C.; Lee, C.-W.; Mutoh, T.; Lin, M.-E.; Teo, S.T.; Park, K.E.; Mosley, A.N.; et al. LPA Receptors: Subtypes and Biological Actions. Annu. Rev. Pharmacol. Toxicol. 2010, 50, 157-186. [CrossRef] [PubMed]

32. Magnússon, M.K.; Halldórsson, H.; Kjeld, M.; Thorgeirsson, G. Endothelial Inositol Phosphate Generation and Prostacyclin Production in Response to G-Protein Activation by AlF4-. Biochem. J. 1989, 264, 703-711. [CrossRef] [PubMed]

33. Pahlavan, S.; Oberhofer, M.; Sauer, B.; Ruppenthal, S.; Tian, Q.; Scholz, A.; Kaestner, L.; Lipp, P. G $\alpha$ q and G $\alpha 11$ Contribute to the Maintenance of Cellular Electrophysiology and $\mathrm{Ca}^{2+}$ Handling in Ventricular Cardiomyocytes. Cardiovasc. Res. 2012, $95,48-58$. [CrossRef] [PubMed]

34. Sunyer, T.; Monastirsky, B.; Codina, J.; Birnbaumer, L. Studies on Nucleotide and Receptor Regulation of Gi Proteins: Effects of Pertussis Toxin. Mol. Endocrinol. 1989, 3, 1115-1124. [CrossRef]

35. Jeon, J.-P.; Hong, C.; Park, E.J.; Jeon, J.-H.; Cho, N.-H.; Kim, I.-G.; Choe, H.; Muallem, S.; Kim, H.J.; So, I. Selective Gai Subunits as Novel Direct Activators of Transient Receptor Potential Canonical (TRPC) 4 and TRPC5 Channels. J. Biol. Chem. 2012, 287, 17029-17039. [CrossRef] [PubMed] 
36. Danielczok, J.; Hertz, L.; Ruppenthal, S.; Kaiser, E.; Petkova-Kirova, P.; Bogdanova, A.; Krause, E.; Lipp, P.; Freichel, M.; Birnbaumer, L.; et al. Does Erythropoietin Regulate TRPC Channels in Red Blood Cells? Cell Physiol. Biochem. 2017, 41, 1219-1228. [CrossRef] [PubMed]

37. Foller, M.; Kasinathan, R.S.; Koka, S.; Lang, C.; Shumilina, E.V.; Birnbaumer, L.; Lang, F.; Huber, S.M. TRPC6 Contributes to the $\mathrm{Ca}(2+)$ Leak of Human Erythrocytes. Cell Physiol. Biochem. 2008, 21, 183-192. [CrossRef]

38. Klarl, B.A.; Lang, P.A.; Kempe, D.S.; Niemoeller, O.M.; Akel, A.; Sobiesiak, M.; Eisele, K.; Podolski, M.; Huber, S.M.; Wieder, T.; et al. Protein Kinase C Mediates Erythrocyte "Programmed Cell Death" Following Glucose Depletion. Am. J. Physiol. Cell Physiol. 2006, 290, C244-C253. [CrossRef] [PubMed]

39. Martiny-Baron, G.; Kazanietz, M.G.; Mischak, H.; Blumberg, P.M.; Kochs, G.; Hug, H.; Marmé, D.; Schächtele, C. Selective Inhibition of Protein Kinase C Isozymes by the Indolocarbazole Gö 6976. J. Biol. Chem. 1993, 268, 9194-9197. [CrossRef]

40. Urban, N.; Wang, L.; Kwiek, S.; Rademann, J.; Kuebler, W.M.; Schaefer, M. Identification and Validation of Larixyl Acetate as a Potent TRPC6 Inhibitor. Mol. Pharmacol. 2016, 89, 197-213. [CrossRef]

41. Maier, T.; Follmann, M.; Hessler, G.; Kleemann, H.; Hachtel, S.; Fuchs, B.; Weissmann, N.; Linz, W.; Schmidt, T.; Löhn, M.; et al. Discovery and Pharmacological Characterization of a Novel Potent Inhibitor of Diacylglycerol-sensitive TRPC Cation Channels. Brit. J. Pharmacol. 2015, 172, 3650-3660. [CrossRef]

42. Bousquet, S.M.; Monet, M.; Boulay, G. Protein Kinase C-Dependent Phosphorylation of Transient Receptor Potential Canonical 6 (TRPC6) on Serine 448 Causes Channel Inhibition. J. Biol. Chem. 2010, 285, 40534-40543. [CrossRef] [PubMed]

43. Kim, J.Y. Activation of M1 Muscarinic Acetylcholine Receptors Stimulates the Formation of a Multiprotein Complex Centered on TRPC6 Channels. J. Biol. Chem. 2005, 280, 32035-32047. [CrossRef]

44. Sartori, M.; Ceolotto, G.; Semplicini, A. MAPKinase and Regulation of the Sodium-Proton Exchanger in Human Red Blood Cell. Biochim. Biophys. Acta 1999, 1421, 140-148. [CrossRef]

45. Kaestner, L.; Wang, X.; Hertz, L.; Bernhardt, I. Voltage-Activated Ion Channels in Non-Excitable Cells-A Viewpoint Regarding Their Physiological Justification. Front. Physiol. 2018, 9, 450. [CrossRef]

46. Hertz, L.; Wang, X.; Jansen, J.; Qiao, M.; Fermo, E.; Zaninoni, A.; Colombatti, R.; Bernhardt, I.; Wagner, C.; Bianchi, P.; et al. Mechanistic Ion-Channel Interactions in Red Cells of Gárdos Channelopathy Patients. Blood Adv. 2021, in revision.

47. Kaushal, V.; Koeberle, P.D.; Wang, Y.; Schlichter, L.C. The $\mathrm{Ca}^{2+}$-Activated K+ Channel KCNN4/KCa3.1 Contributes to Microglia Activation and Nitric Oxide-Dependent Neurodegeneration. J. Neurosci. 2007, 27, 234-244. [CrossRef] [PubMed]

48. Duncia, J.V.; Santella, J.B.; Higley, C.A.; Pitts, W.J.; Wityak, J.; Frietze, W.E.; Rankin, F.W.; Sun, J.H.; Earl, R.A.; Tabaka, A.C.; et al. MEK Inhibitors: The Chemistry and Biological Activity of U0126, Its Analogs, and Cyclization Products. Bioorg. Med. Chem. Lett. 1998, 8, 2839-2844. [CrossRef]

49. Ui, M.; Okada, T.; Hazeki, K.; Hazeki, O. Wortmannin as a Unique Probe for an Intracellular Signalling Protein, Phosphoinositide 3-Kinase. Trends Biochem. Sci. 1995, 20, 303-307. [CrossRef]

50. Hui, X.; Kaestner, L.; Lipp, P. Differential Targeting of CPKC and NPKC Decodes and Regulates Ca ${ }^{2+}$ and Lipid Signalling. Biochem. Soc. Trans. 2014, 42, 1538-1542. [CrossRef]

51. Danielczok, J.G.; Terriac, E.; Hertz, L.; Petkova-Kirova, P.; Lautenschläger, F.; Laschke, M.W.; Kaestner, L. Red Blood Cell Passage of Small Capillaries Is Associated with Transient $\mathrm{Ca}^{2+}$-Mediated Adaptations. Front. Physiol. 2017, 8, 979. [CrossRef] [PubMed]

52. Zarychanski, R.; Schulz, V.P.; Houston, B.L.; Maksimova, Y.; Houston, D.S.; Smith, B.; Rinehart, J.; Gallagher, P.G. Mutations in the Mechanotransduction Protein PIEZO1 Are Associated with Hereditary Xerocytosis. Blood 2012, 120, 1908-1915. [CrossRef] [PubMed]

53. Albuisson, J.; Murthy, S.E.; Bandell, M.; Coste, B.; Louis-dit-Picard, H.; Mathur, J.; Fénéant-Thibault, M.; Tertian, G.; de Jaureguiberry, J.P.; Syfuss, P.Y.; et al. Dehydrated Hereditary Stomatocytosis Linked to Gain-of-Function Mutations in Mechanically Activated PIEZO1 Ion Channels. Nat. Commun. 2013, 4, 1-9. [CrossRef]

54. Andolfo, I.; Alper, S.L.; Franceschi, L.D.; Auriemma, C.; Russo, R.; Falco, L.D.; Vallefuoco, F.; Esposito, M.R.; Vandorpe, D.H.; Shmukler, B.E.; et al. Multiple Clinical Forms of Dehydrated Hereditary Stomatocytosis Arise from Mutations in PIEZO1. Blood 2013, 121, 3925-3935. [CrossRef] [PubMed]

55. Bae, C.; Sachs, F.; Gottlieb, P.A. The Mechanosensitive Ion Channel Piezo1 Is Inhibited by the Peptide GsMTx4. Biochemistry 2011, 50, 6295-6300. [CrossRef] [PubMed]

56. Hui, X.; Reither, G.; Kaestner, L.; Lipp, P. Targeted Activation of Conventional and Novel Protein Kinase C through Differential Translocation Patterns. Mol. Cell Biol. 2014, 34, 2370-2381. [CrossRef]

57. Bernhardt, I.; Ellory, J.C. (Eds.) Red Cell Membrane Transport in Health and Disease; Springer Science \& Business Media: Cham, Switzerland, 2003; ISBN 9783540442271.

58. Kaestner, L.; Minetti, G. The Potential of Erythrocytes as Cellular Aging Models. Cell Death Differ. 2017, 24, 1475-1477. [CrossRef] [PubMed]

59. Korell, J.; Coulter, C.V.; Duffull, S.B. Evaluation of Red Blood Cell Labelling Methods Based on a Statistical Model for Red Blood Cell Survival. J. Theor. Biol. 2011, 291, 88-98. [CrossRef] [PubMed]

60. Hertz, L.; Ruppenthal, S.; Simionato, G.; Quint, S.; Kihm, A.; Abay, A.; Petkova-Kirova, P.; Boehm, U.; Weissgerber, P.; Wagner, C.; et al. The Evolution of Erythrocytes Becoming Red in Respect to Fluorescence. Front. Physiol. 2019, 10, 753. [CrossRef] [PubMed]

61. Grygorczyk, R.; Schwarz, W.; Passow, H. Ca ${ }^{2+}$-Activated K+ Channels in Human Red Cells. Comparison of Single-Channel Currents with Ion Fluxes. Biophys. J. 1984, 45, 693-698. [CrossRef] 
62. Wolff, D.; Cecchi, X.; Spalvins, A.; Canessa, M. Charybdotoxin Blocks with High Affinity the Ca-Activated K+ Channel of Hb A and $\mathrm{Hb} \mathrm{S}$ Red Cells: Individual Differences in the Number of Channels. J. Membr. Biol. 1988, 106, 243-252. [CrossRef]

63. Kaestner, L. Channelizing the Red Blood Cell: Molecular Biology Competes with Patch-Clamp. Front. Mol. Biosci. 2015, 2, 46. [CrossRef]

64. Flora, A.D.; Damonte, G.; Sdraffa, A.; Franco, L.; Benatti, U. Heterogeneity of Guanine Nucleotide Binding Proteins in Human Red Blood Cell Membranes. Adv. Exp. Med. Biol. 1991, 307, 161-171. [PubMed]

65. Bogdanova, A.; Makhro, A.; Goede, J.; Wang, J.; Boldyrev, A.; Gassmann, M.; Kaestner, L. NMDA Receptors in Mammalien Erythrocytes. Clin. Biochem. 2009, 42, 1858-1859. [CrossRef]

66. McCurdy, P.R.; Sherman, A.S. Irreversibly Sickled Cells and Red Cell Survival in Sickle Cell Anemia A Study with Both DF32P and 51CR. Am. J. Med. 1978, 64, 253-258. [CrossRef]

67. Noh, J.-Y.; Lim, K.-M.; Bae, O.-N.; Chung, S.-M.; Lee, S.-W.; Joo, K.-M.; Lee, S.-D.; Chung, J.-H. Procoagulant and Prothrombotic Activation of Human Erythrocytes by Phosphatidic Acid. Am. J. Physiol. Heart Circ. Physiol. 2010, 299, H347-H355. [CrossRef] [PubMed]

68. Wautier, M.-P.; Nemer, W.E.; Gane, P.; Rain, J.-D.; Cartron, J.-P.; Colin, Y.; Kim, C.L.V.; Wautier, J.-L. Increased Adhesion to Endothelial Cells of Erythrocytes from Patients with Polycythemia Vera Is Mediated by Laminin Alpha5 Chain and Lu/BCAM. Blood 2007, 110, 894-901. [CrossRef] [PubMed]

69. Lauf, P.K. Eryptotic Red Blood Cell Adhesion to Vascular Endothelium: CXCL16/SR-PSOX, a Pathological Amplifier. Focus on "Dynamic Adhesion of Eryptotic Erythrocytes to Endothelial Cells via CXCL16/SR-PSOX". Am. J. Physiol. Cell Physiol. 2012, 302, C642-C643. [CrossRef]

70. Zennadi, R.; Whalen, E.J.; Soderblom, E.J.; Alexander, S.C.; Thompson, J.W.; Dubois, L.G.; Moseley, M.A.; Telen, M.J. Erythrocyte Plasma Membrane-Bound ERK1/2 Activation Promotes ICAM-4-Mediated Sickle Red Cell Adhesion to Endothelium. Blood 2012, 119, 1217-1227. [CrossRef] [PubMed]

71. Bogdanova, A.; Kaestner, L.; Simionato, G.; Wickrema, A.; Makhro, A. Heterogeneity of Red Blood Cells: Causes and Consequences. Front. Physiol. 2020, 11, 392. [CrossRef]

72. Schatzmann, H.J. ATP-Dependent Ca++-Extrusion from Human Red Cells. Experientia 1966, 22, 364-365. [CrossRef] [PubMed]

73. Tiffert, T.; Bookchin, R.M.; Lew, V.L. Calcium Homeostasis in Normal and Abnormal Human Red Cells. In Red Cell Membrane Transport in Health and Disease; Bernhardt, I., Ellory, C., Eds.; Springer: Berlin/Heidelberg, Germany, 2003 ; pp. $373-405$.

74. Birnbaumer, L.; Codina, J.; Mattera, R.; Yatani, A.; Graf, R.; Olate, J.; Sanford, J.; Brown, A.M. Receptor-Effector Coupling by G Proteins: Purification of Human Erythrocyte Gi-2 and Gi-3 and Analysis of Effector Regulation Using Recombinant Alpha Subunits Synthesized in Escherichia Coli. Cold Spring Harb. Symp. Quant. Biol. 1988, 53 Pt 1, 229-239. [CrossRef]

75. AYa, K.; Gumanova, N.G.; Akhmedzhanov, N.M.; Varentsov, S.I.; Gerasimova, C.I.; Bulargina, T.V.; Shakhov, Y.A. The GTPBinding Regulatory Proteins, Gs and G(i), Are Altered in Erythrocyte Membranes of Patients with Ischemic Heart Disease Resulting from Coronary Atherosclerosis. Arterioscl. Thromb. 1993, 13, 1244-1251.

76. Guidetti, G.F.; Lova, P.; Bernardi, B.; Campus, F.; Baldanzi, G.; Graziani, A.; Balduini, C.; Torti, M. The Gi-Coupled P2Y12 Receptor Regulates Diacylglycerol-Mediated Signaling in Human Platelets. J. Biol. Chem. 2008, 283, 28795-28805. [CrossRef] [PubMed]

77. Graham, S.; Gorin, Y.; Abboud, H.E.; Ding, M.; Lee, D.Y.; Shi, H.; Ding, Y.; Ma, R. Abundance of TRPC6 Protein in Glomerular Mesangial Cells Is Decreased by ROS and PKC in Diabetes. Am. J. Physiol. Cell Physiol. 2011, 301, C304-C315. [CrossRef]

78. Wang, Y.; Hill, K.S.; Fields, A.P. PKCı Maintains a Tumor-Initiating Cell Phenotype That Is Required for Ovarian Tumorigenesis. Mol. Cancer Res. 2013, 11, 1624-1635. [CrossRef]

79. Shi, J.; Mori, E.; Mori, Y.; Mori, M.; Li, J.; Ito, Y.; Inoue, R. Multiple Regulation by Calcium of Murine Homologues of Transient Receptor Potential Proteins TRPC6 and TRPC7 Expressed in HEK293 Cells. J. Physiol. 2004, 561, 415-432. [CrossRef]

80. Large, W.A.; Saleh, S.N.; Albert, A.P. Role of Phosphoinositol 4,5-Bisphosphate and Diacylglycerol in Regulating Native TRPC Channel Proteins in Vascular Smooth Muscle. Cell Calcium 2009, 45, 574-582. [CrossRef]

81. Saleh, S.N.; Albert, A.P.; Peppiatt-Wildman, C.M.; Large, W.A. Diverse Properties of Store-Operated TRPC Channels Activated by Protein Kinase C in Vascular Myocytes. J. Physiol. 2008, 586, 2463-2476. [CrossRef]

82. Kauffenstein, G.; Bergmeier, W.; Eckly, A.; Ohlmann, P.; Léon, C.; Cazenave, J.P.; Nieswandt, B.; Gachet, C. The P2Y(12) Receptor Induces Platelet Aggregation through Weak Activation of the Alpha(IIb)Beta(3) Integrin-A Phosphoinositide 3-KinaseDependent Mechanism. FEBS Lett. 2001, 505, 281-290. [CrossRef]

83. Soulet, C.; Sauzeau, V.; Plantavid, M.; Herbert, J.M.; Pacaud, P.; Payrastre, B.; Savi, P. Gi-Dependent and -Independent Mechanisms Downstream of the P2Y12 ADP-Receptor. J. Thromb. Haemost. 2004, 2, 135-146. [CrossRef] [PubMed]

84. Hille, B. Modulation of Ion-Channel Function by G-Protein-Coupled Receptors. Trends Neurosci. 1994, 17, 531-536. [CrossRef]

85. Kotturi, M.F.; Carlow, D.A.; Lee, J.C.; Ziltener, H.J.; Jefferies, W.A. Identification and Functional Characterization of VoltageDependent Calcium Channels in T Lymphocytes. J. Biol. Chem. 2003, 278, 46949-46960. [CrossRef] [PubMed]

86. Badou, A.; Jha, M.K.; Matza, D.; Mehal, W.Z.; Freichel, M.; Flockerzi, V.; Flavell, R.A. Critical Role for the Beta Regulatory Subunits of Cav Channels in T Lymphocyte Function. Proc. Natl. Acad. Sci. USA 2006, 103, 15529-15534. [CrossRef] [PubMed]

87. Jha, M.K.; Badou, A.; Meissner, M.; McRory, J.E.; Freichel, M.; Flockerzi, V.; Flavell, R.A. Defective Survival of Naive CD8+ T Lymphocytes in the Absence of the Beta3 Regulatory Subunit of Voltage-Gated Calcium Channels. Nat. Immunol. 2009, 10, 1275-1282. [CrossRef] [PubMed] 